\title{
Optimization of the Linker Length of Mannose-Cholesterol Conjugates for Enhanced mRNA Delivery to Dendritic Cells by Liposomes
}

\section{OPEN ACCESS}

Edited by:

Chao Wang,

The University of North Carolina at Chapel Hill, United States

Reviewed by:

Xiaoqi Sun

University of Michigan, United States

Rahul K. Keswani,

Exelead, Inc., United States

Wenmin Yuan,

University of Michigan, United States

*Correspondence:

Xiangrong Song

songxr@scu.edu.cn

Jinhui Wu

wujinhui@scu.edu.cn

Mohamed M. S. Farag

mohamed.farag@azhar.edu.eg

tThese authors have contributed equally to this work

Specialty section:

This article was submitted to Experimental Pharmacology and Drug

Discovery,

a section of the journal

Frontiers in Pharmacology

Received: 21 May 2018

Accepted: 09 August 2018 Published: 05 September 2018

Citation:

Wang F, Xiao W, Elbahnasawy MA

Bao X, Zheng Q, Gong L, Zhou Y,

Yang S, Fang A, Farag MMS, Wu J and Song $X$ (2018) Optimization of the Linker Length of Mannose-Cholesterol Conjugates for Enhanced mRNA Delivery to Dendritic Cells by Liposomes. Front. Pharmacol. 9:980. doi: 10.3389/fphar.2018.00980
Fazhan Wang ${ }^{1 \dagger}$, Wen Xiao ${ }^{1+}$, Mostafa A. Elbahnasawy ${ }^{2 t}$, Xingting Bao', Qian Zheng ${ }^{1}$, Linhui Gong ${ }^{1}$, Yang Zhou ${ }^{1}$, Shuping Yang ${ }^{1}$, Aiping Fang ${ }^{1}$, Mohamed M. S. Farag ${ }^{2 *}$, Jinhui $\mathrm{Wu}^{1 *}$ and Xiangrong Song ${ }^{1 *}$

1 State Key Laboratory of Biotherapy, Geriatrics and Cancer Center, West China Hospital, and Collaborative Innovation Center for Biotherapy, Sichuan University, Chengdu, China, ${ }^{2}$ Department of Botany and Microbiology, Faculty of Science, Al-Azhar University, Cairo, Egypt

Liposomes (LPS) as commonly used mRNA delivery systems remain to be rationally designed and optimized to ameliorate the antigen expression of mRNA vaccine in dendritic cells (DCs). In this study, we synthesized mannose-cholesterol conjugates $\left(\mathrm{MP}_{\mathrm{n}}-\mathrm{CHs}\right.$ ) by click reaction using different PEG units ( $P E G_{100}, P E G_{1000}$, and $\left.P E G_{2000}\right)$ as linker molecules. $\mathrm{MP}_{\mathrm{n}}-\mathrm{CH}$ s were fully characterized and subsequently used to prepare DC-targeting liposomes (MP $\mathrm{n}_{\mathrm{n}}$-LPs) by a thin-film dispersion method. $\mathrm{MP}_{\mathrm{n}}$-LPs loaded with mRNA (MP $\mathrm{n}_{\mathrm{n}}$-LPX) were finally prepared by a simple self-assembly method. $M P_{n}-L P X$ displayed bigger diameter (about $135 \mathrm{~nm}$ ) and lower zeta potential (about $40 \mathrm{mV}$ ) compared to $\mathrm{MP}_{\mathrm{n}}$-LPs. The in vitro transfection experiment on DC2.4 cells demonstrated that the PEG length of mannose derivatives had significant effect on the expression of GFP-encoding mRNA. MP $1000-\mathrm{LPX}$ containing $\mathrm{MP}_{1000}-\mathrm{CH}$ can achieve the highest transfection efficiency $(52.09 \pm 4.85 \%)$, which was significantly superior to the commercial transfection reagent Lipo $3 \mathrm{~K}(11.47 \pm 2.31 \%)$. The optimal DC-targeting $\mathrm{MP}_{1000}$-LPX showed an average size of $132.93 \pm 4.93 \mathrm{~nm}$ and zeta potential of $37.93 \pm 2.95 \mathrm{mV}$ with nearly spherical shape. Moreover, MP 1000 -LPX can protect $m R N A$ against degradation in serum with high efficacy. The uptake study indicated that $\mathrm{MP}_{1000}$-LPX enhanced mRNA expression mainly through the over-expressing mannose receptor (CD206) on the surface of DCs. In conclusion, mannose modified LPs might be a potential DC-targeting delivery system for mRNA vaccine after rational design and deserve further study on the in vivo delivery profile and anti-tumor efficacy.

Keywords: mRNA vaccine, dendritic cell targeting liposomes, mannose conjugates, linker length, click reaction

\section{INTRODUCTION}

Messenger RNA (mRNA) has recently generated great attention as one of promising therapeutics with the potential for cancer immunotherapy and vaccines because the in vitrotranscribed (IVT) mRNA does not need to enter the nucleus and induces only transient protein expression without the risk of genomic integration compared with the widely investigated DNA (Sahin et al., 2014; Pardi et al., 2018). Some mRNA vaccines have been demonstrated to be effective in the preclinical mouse models of cancer (Kreiter et al., 2015; 
Oberli et al., 2017; Sayour et al., 2017). Nevertheless, the anionic character of mRNA does not facilitate its penetration into cells, resulting in low antigen expression and curative effect. It has been shown that the cellular uptake rate of naked mRNA is less than 1 in 10,000 molecules (Sahin et al., 2014). Moreover, mRNA is prone to degradation by RNases present everywhere (Tsui et al., 2002). Thus, sufficiently efficacious delivery system is urgently required to target antigen presentation cells (APCs) and protect mRNA from nuclease degradation, which will be beneficial for the clinical application of more mRNA vaccines (Pardi et al., 2018).

Non-viral vectors such as lipids, lipid-like materials, polymer or hybrid systems are widely studied for delivery of mRNA vaccines, which have low unwanted immune responses in contrast to the viral systems including adeno- associated viruses, lentiviruses and the Sendai virus (Giacca and Zacchigna, 2012; Midoux and Pichon, 2015; Hajj and Whitehead, 2017). Liposomes (LPs) are the most appealing and commonly used non-viral carriers of mRNA vaccines (Markov et al., 2015; Kranz et al., 2016; Persano et al., 2017; Verbeke et al., 2017). The mRNA loaded LPs namely RNA-LPX for cancer immunotherapy have been in phase I dose-escalation trial (Kranz et al., 2016). RNA-LPX protected mRNA from RNases and the encoded antigen can be efficiently expressed in the specialized APCs, like DCs (Kranz et al., 2016). Furthermore, the antigen-specific T-cell responses were also induced in melanoma patients. However, only 1 in 3 patients showed regression of a suspected metastatic thoracic lymph node lesion. The limited antitumor efficacy of RNALPX indicated that the LPs were worthy of being further reformed by functionalization of particles with ligands targeting DCs.

Dendritic cells express several mannose residue-recognizing membrane lectins like CD206 (mannose receptor, MR), CD209 (DC-SIGN) and CD207 (langerin) (Caminschi et al., 2012; Le Moignic et al., 2018). Macrophages as also expressed CD206 receptor (Chen et al., 2016; Kim et al., 2017) with the ability to present antigens (Malissen et al., 2014). They can mediate endocytosis of cargos encapsulated in mannose-modified nano-preparations (Li et al., 2013; Chen et al., 2014; Wang C. et al., 2014). Of note, enhanced in vivo anticancer efficacy via mannose modification on the nano-preparations has been widely reported in the literatures (Lai et al., 2018; Le Moignic et al., 2018; Yang et al., 2018). LPs can be easily modified because phospholipids and cholesterol are typically included (Hua and $\mathrm{Wu}, 2013$ ). These lipophilic molecules can conjugate with various moieties binding to surface receptors of the target cells with high selectivity. Our previous studies demonstrated that folic acid-conjugating LPs can specifically deliver DNA into folate receptor-overexpressing tumor (He Z.Y. et al., 2013; Yang et al., 2016). The targeting molecule folic acid was linked to cholesterol, which efficiently kept its binding specificity to folate receptor (He Z. et al., 2013). Taking into account of these, mannosylated cholesterol derivatives were designed and synthesized to prepare mannosylated LPs to help delivery to DCs in this study.

According to literatures, the length and flexibility of the space between ligand molecules and the surface of particles might be important parameters for efficient recognition of receptors (Engel et al., 2003; Stefanick et al., 2013; Jeong et al., 2014). A short linker may restrict the translational freedom of ligand, while the longer one might bury a large fraction of the conjugated ligand (Stefanick et al., 2013). The optimal linker provides a more effective ligand-receptor interaction (Stefanick et al., 2013; Jeong et al., 2014). Thus, a rational design of the targeting LPs is crucial to enhanced mRNA delivery to DCs.

In our study, $\mathrm{MP}_{\mathrm{n}}$-CHs containing different $\mathrm{PEG}$ units were firstly synthesized and then used to prepare the $\mathrm{MP}_{\mathrm{n}}$-LPs by a typical thin-film dispersion method. The mRNA encapsulating liposomes $\left(\mathrm{MP}_{\mathrm{n}}-\mathrm{LPX}\right)$ were constructed by complexing the obtained $\mathrm{MP}_{\mathrm{n}}$-LPs and mRNA. The preferable $\mathrm{MP}_{\mathrm{n}}$-LPX were picked out according to the in vitro transfection efficiency of GFP-encoding mRNA on DCs. The pharmaceutical properties and preliminary cytotoxicity of the optimal delivery system were also assessed to favor its potential application for mRNA delivery.

\section{MATERIALS AND METHODS}

\section{Materials}

1,2,3,4,6-Penta-O-acetyl-alpha-D-mannopyranoside was obtained from Jinan Samuel Pharmaceutical Co., Ltd. (Shandong, China). Cholesterol was supplied from Shanghai Yuanju Biology Technology Company (Shanghai, China). Cholesterol$\mathrm{PEG}_{2000}-\mathrm{N}_{3}$ was purchased by Shanghai Ponsure Biotech, Inc (Shanghai, China). 1,2-dioleoyl-3-trimethylammonium-propane (DOTAP) and 1,2-dioleoyl-sn-glycero-3-phosphoethanolamine (DOPE) was provided by Shanghai A.V.T. Pharmaceutical Co., Ltd. (Shanghai, China). GFP-mRNA was obtained from TriLink (San Diego, CA, United States). DMEM and fetal bovine serum (FBS) were purchased from Gibco. All the other chemical reagents were of analytical grade or better without further purification unless otherwise stated.

\section{Cell Culture}

DC2.4 cells were cultured in DMEM medium supplemented with $10 \% \mathrm{FBS}$ and $1 \%$ penicillin/streptomycin with $5 \% \mathrm{CO}_{2}$ at $37^{\circ} \mathrm{C}$ in a humidified atmosphere.

\section{Synthesis and Characterization of $\mathrm{MP}_{\mathrm{n}}-\mathrm{CH}$ Synthesis of $\mathrm{MP}_{100}-\mathrm{CH}$}

As shown in Figure $\mathbf{1 A}, \mathrm{MP}_{100}-\mathrm{CH}$ was obtained with similar procedures as described previously (Kim et al., 2012; Nguyen et al., 2016). In brief, Diethylene glycol (5.0 eq), paratoluensulfonyl chloride ( $\operatorname{Tos} \mathrm{Cl}, 1.0 \mathrm{eq}$ ) and triethylamine (TEA, $1.1 \mathrm{eq})$ were dissolved in anhydrous dichloromethane (DCM) and stirred for 24 hours (h) at room temperature (rt). The crude product was purified by silica gel with a mixed solvent system of DCM and methanol to harvest compound 1. 1,2,3,4,6-Penta- $O$-acetyl-alpha-D-mannopyranoside (1.5 eq), compound 1 (1.0 eq) and $\mathrm{BF}_{3} \cdot \mathrm{Et}_{2} \mathrm{O}(1.5 \mathrm{eq})$ were dissolved in anhydrous DCM. Compound 2 was acquired and purified by column chromatography. Compound 2 (1.0 eq) and sodium 


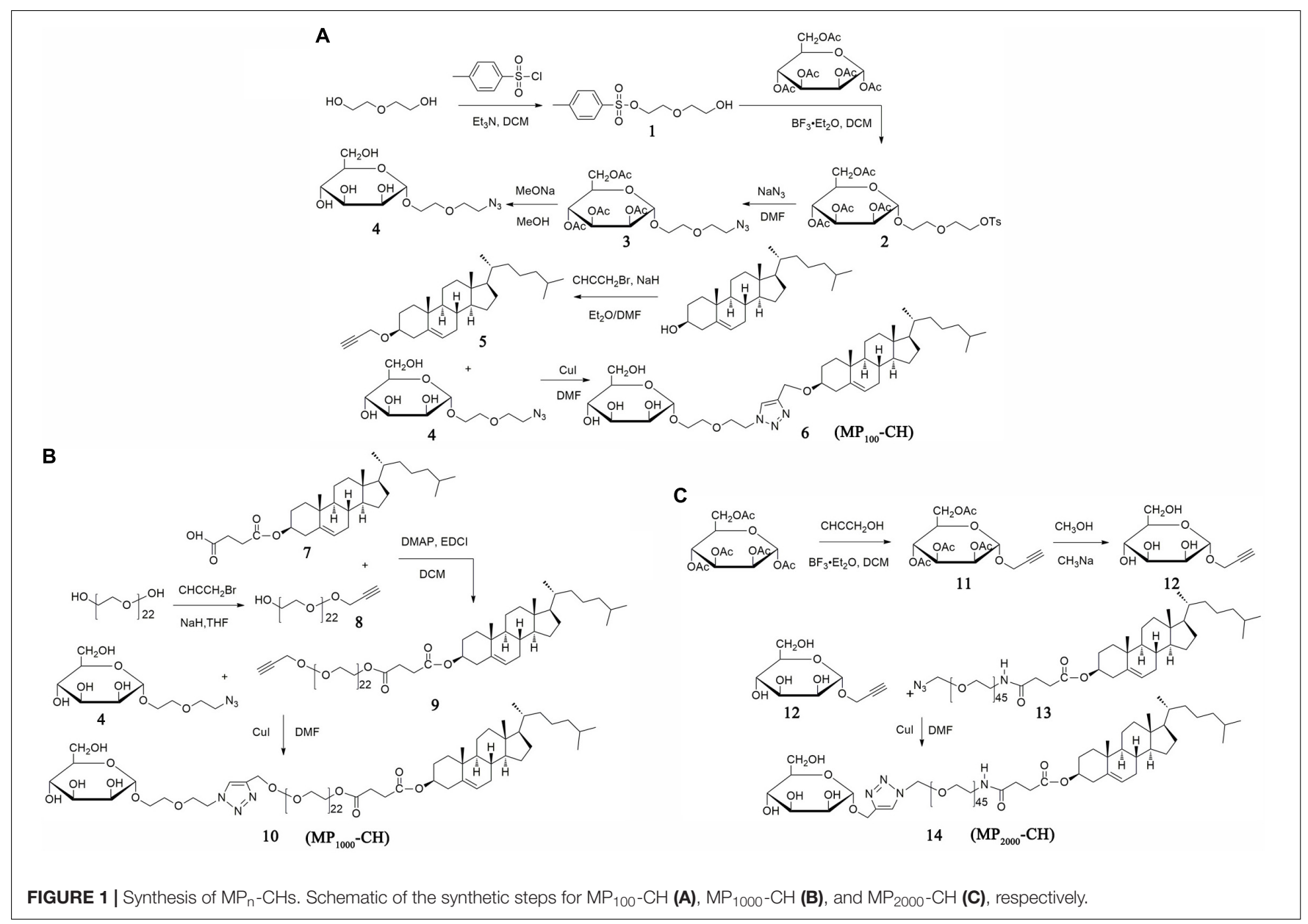

azide (5.0 eq) were added into anhydrous $\mathrm{N}, \mathrm{N}$-dimethylFormamide (DMF) and stirred suitably for $24 \mathrm{~h}$ at $60^{\circ} \mathrm{C}$ to prepare compound 3. Subsequently, deacetylation of compound 3 was performed in methanol solution (HPLC grade) of sodium methoxide (NaOMe) $(10: 1, \mathrm{v} / \mathrm{v})$. Then the reaction system was treated with $(\mathrm{H}+)$ resin to get product named compound 4. Compound 5 was prepared as described previously (RullBarrull et al., 2016). In brief, Cholesterol (1.0 eq) and 3bromopropyne $(2.0 \mathrm{eq})$ were dissolved in component solvent containing anhydrous ether and anhydrous DMF (1:1, v/v). Sodium hydride $(\mathrm{NaH}, 5.0 \mathrm{eq})$ was added mildly and the solution was stirred at rt for $24 \mathrm{~h}$. Finally, compound 4, compound 5 and copper iodide were mixed in equal molar ratio and dissolved in anhydrous DMF. The mixture was reacted for $24 \mathrm{~h}$ at $\mathrm{rt}$ and concentrated to obtained compound $6\left(\mathrm{MP}_{100}-\mathrm{CH}\right)$ via column chromatography.

\section{Synthesis of $\mathrm{MP}_{1000}-\mathrm{CH}$}

The synthetic scheme was shown in Figure $\mathbf{1 B}$ and specific experimental steps were as follows. Compound 7 was prepared and purified according to our previously reported method (He Z.Y. et al., 2010). PEG 1000 (5.0 eq), propargyl bromide $(2.0$ eq) and hydrogenated sodium $(\mathrm{NaH}, 3.0$ eq) were dissolved in anhydrous tetrahydrofuran (THF). The mixture was stirred at rt overnight. Compound $\mathbf{8}$ was purified by column chromatography. Compound 7 (1.2 eq), 8 (1.0 eq), DMAP (0.5 eq), and EDCI (2.0 eq) were dissolved in DCM and stirred at $\mathrm{rt}$ for $24 \mathrm{~h}$. Compound 9 was obtained after the crude product was purified by column chromatography. Similar to the synthetic method of compound 6, compound 4 was connected to compound 9 , and compound $10\left(\mathrm{MP}_{1000}-\mathrm{CH}\right)$ was obtained.

\section{Synthesis of $\mathrm{MP}_{2000}-\mathrm{CH}$}

Compound 14 were prepared according to the scheme showed in Figure 1C. Briefly, compound $\mathbf{1 1}$ was prepared according to the synthesis method of compound 2 but replace the compound 1 with propargyl alcohol. Subsequently, compound 12 was acquired using the similar synthesis method of compound 4. Compound $14\left(\mathrm{MP}_{2000}-\mathrm{CH}\right)$ was obtained with the similar synthesis method of compound 10 after column chromatography.

\section{General Characterization of Prepared Compounds}

${ }^{1} \mathrm{H}-\mathrm{NMR}$ spectra of $\mathrm{MP}_{\mathrm{n}}-\mathrm{CH}$ and other prepared compounds dissolved in $\mathrm{CDCl}_{3}, \mathrm{D}_{2} \mathrm{O}$ or Dimethyl Sulfoxide- $\mathrm{D}_{6}$ containing TMS were recorded on a Unity Inova-400 (400 MHz) (Varian Inc., Palo Alto, CA, United States). Chemical shifts were analyzed in $\mathrm{ppm}$ relative to the residual solvent peaks of TMS. The 
mass spectra of various compounds were obtained using a Waters Q-TOF Premier (Milford, MA, United States) equipped with the ion spray source and using $\mathrm{N}_{2}$ as nebulization gas. In addition, the identity of the conjugate was also verified by Fourier Transform infrared spectroscopy (FTIR) using a Vector 22 spectrometer (Bruker, Ettlingen, Switzerland). The purity and retention time of $\mathrm{MP}_{\mathrm{n}}-\mathrm{CHs}$ and other cholesterol derivatives were evaluated by high performance liquid chromatography (HPLC, Waters, Milford, MA, United States) at $201 \mathrm{~nm}$. The mobile phase, at $1 \mathrm{~mL} / \mathrm{min}$ flow rate, was composed of $100 \%$ chromatographic methanol. The retention time and purity of cholesterol derivatives were summarized in Table 1.

\section{Preparation and Characterization of $M P_{n}-L P X$ \\ Preparation of $\mathrm{MP}_{\mathrm{n}}$-LPs}

The cationic LPs were prepared using a thin-film dispersion method with some modifications (Wang F. et al., 2018). Briefly, cationic lipid DOTAP, the helper lipid DOPE, $\mathrm{CH}$ and $\mathrm{MP}_{\mathrm{n}}-\mathrm{CH}$ at a molar ratio of 50:10:35:5 or 50:10:40:0 (Table 2) were dissolved in a mixture solvent of chloroform/ethanol $(1: 1, \mathrm{v} / \mathrm{v})$ to prepare $\mathrm{MP}_{\mathrm{n}}$-LPs and LPs, respectively. The organic solvents were evaporated using a rotary evaporator at $37^{\circ} \mathrm{C}$ for $2 \mathrm{~h}$. The lipid film was rehydrated with $2 \mathrm{~mL}$ RNase-free water at $60^{\circ} \mathrm{C}$ for $40 \mathrm{~min}$ to obtain a suspension with the final lipid concentration of $6 \mathrm{mM}$. Subsequently, the above suspension was sonicated at $80 \mathrm{~W}$ for $3 \mathrm{~min}$ and filtered with a $0.22 \mu \mathrm{m}$ sterilized filter for the following experiment. The coumarin- 6 (Cou-6) loaded LPs were acquired using the similar procedure with the addition of Cou- 6 into the chloroform/ethanol (1:1 v/v) solvent mixture. The fluorescent intensity of Cou- 6 loaded particles was measured using CyrationTM3 (BioTek Instruments, Inc, United States).

\section{Preparation of $\mathrm{MP}_{\mathrm{n}}-\mathrm{LPX}$}

In our study, $\mathrm{MP}_{\mathrm{n}}$-LPX was composed of DOTAP contained LPs and mRNA at N/P ratio of 3,5 or 7 , named $M P_{n}-L P X$ $\mathrm{NP} 3, \mathrm{MP}_{\mathrm{n}}$-LPX NP 5 or $\mathrm{MP}_{\mathrm{n}}$-LPX NP 7, respectively. $\mathrm{MP}_{\mathrm{n}}$-LPX were prepared according to previous reported methods with some modifications (Kranz et al., 2016). Briefly, mRNA was diluted by water and $1.5 \mathrm{M} \mathrm{NaCl}$ followed by adding corresponding $\mathrm{MP}_{\mathrm{n}}$-LPs diluted with water to reach the desired ratio of $\mathrm{N} / \mathrm{P}$ with the final concentration of $\mathrm{NaCl}$ of $150 \mathrm{mM}$.
After incubated at $\mathrm{rt}$ for $15 \mathrm{~min}, \mathrm{MP}_{\mathrm{n}}$-LPX were finally obtained.

\section{Size and Zeta Potential Measurements}

The average particle size, size distribution (polydispersity index, PDI) and zeta potential of different formulations were recorded by Zetasizer Nano ZS90 (Malvern Instruments, Malvern, United Kingdom). All measurements were carried out using diluted samples at $25^{\circ} \mathrm{C}$ and were conducted in triplicate.

\section{Cellular Transfection of $\mathrm{MP}_{\mathbf{n}}-\mathrm{LPX}$}

To optimize the appropriate ratio of N/P, DC2.4 cells in the logarithmic growth period were seeded in 24 well plates at $4 \times 10^{5}$ cells/well and incubated for $24 \mathrm{~h}$ at $37^{\circ} \mathrm{C}$, followed by incubation with different N/P of LPX ( $0.5 \mu \mathrm{g}$ GFP-mRNA per well) in triplicate from 3 to 7 . Before transfection, the culture medium was replaced with $500 \mu \mathrm{L}$ FBS-free DMEM. Subsequently, LPX were added. After $4 \mathrm{~h}$ of incubation, $500 \mu \mathrm{L}$ complete medium was added, and the cells were incubated for another 20 h. Expression of GFP by DC2.4 cells was visualized using a fluorescence microscope (Olympus Corp., Tokyo, Japan) and transfection efficiency was obtained based on the percentage of GFP positive cells from the live cell population by flow cytometry. Additionally, mean GFP fluorescence intensity of individual cells from GFP positive cells population after transfection was measured using FlowJo software (Li et al., 2017b).

To further investigate the transfection efficiency of $\mathrm{MP}_{\mathrm{n}}-\mathrm{LPX}$, DC2.4 cells in 24 well plates were incubated with $\mathrm{MP}_{\mathrm{n}}-\mathrm{LPX}$ with the N/P of 5 following the same procedure described above. Transfection efficiency and mean fluorescence intensity (MFI) of GFP positive DC2.4 cells were evaluated by flow cytometry. In brief, DC2.4 cells were captured via forward scatter (FSC) and side scatter (SSC). Live DC2.4 cells were gated as shown in Region 1 (R1), of which GFP positive cells were selected (R2). Transfection efficiency (\% $\mathrm{GFP}^{+}$cells) was auto displayed with R2. MFI of GFP expression in GFP positive cells was acquired using FlowJo software. MFI was calculated after subtraction of background values of untreated DC2.4 cells. To further elaborate the kinetics of mRNA transfection in vitro, transfection efficiency of $\mathrm{MP}_{1000}$-LPX NP 5 on DC2.4 cells from 12 to $72 \mathrm{~h}$ has also been studied.

TABLE 1 | The retention time and purity of cholesterol derivatives was evaluated by HPLC.

\begin{tabular}{|c|c|c|c|c|c|c|}
\hline & \multicolumn{2}{|c|}{ Peak 1} & \multicolumn{2}{|c|}{ Peak 2} & \multicolumn{2}{|c|}{ Peak 3} \\
\hline & Time (min) & Purity (\%) & Time (min) & Purity (\%) & Time (min) & Purity (\%) \\
\hline Compound 6 & 9.743 & 97.948 & 10.493 & 1.996 & - & - \\
\hline Compound 9 & 7.14 & 2.9 & 11.557 & 2.204 & 16.692 & 94.881 \\
\hline Compound 10 & 7.548 & 1.627 & 11.556 & 1.878 & 13.122 & 96.495 \\
\hline Compound $\mathbf{1 3}$ & - & - & 10.278 & 8.749 & 13.662 & 91.251 \\
\hline Compound 14 & 6.907 & 91.532 & 10.896 & 2.321 & 13.796 & 6.147 \\
\hline
\end{tabular}

Bold values represents the retention time and purity of each compound. 
TABLE 2 | Formulation component and relative molar content used in the manuscript.

\begin{tabular}{lcccc}
\hline & LPs & MP $_{\mathbf{1 0 0}}$-LPs & MP $_{\mathbf{1 0 0 0}}$-LPs & MP $_{\mathbf{2 0 0 0}}$-LPs \\
\hline DOTAP & 50 & 50 & 50 & 50 \\
DOPE & 10 & 10 & 10 & 10 \\
$\mathrm{CH}$ & 40 & 35 & 35 & 35 \\
$\mathrm{MP}_{100}-\mathrm{CH}$ & 0 & 5 & 0 & 0 \\
$\mathrm{MP}_{1000}-\mathrm{CH}$ & 0 & 0 & 5 & 0 \\
$\mathrm{MP}_{2000}-\mathrm{CH}$ & 0 & 0 & 0 & 5 \\
\hline
\end{tabular}

\section{Characterization of Optimal $\mathrm{MP}_{1000}$-LPX Microscopy Investigation}

The appearance and Tyndall effect of $\mathrm{MP}_{1000}$-LX were recorded by a digital camera. The morphology of $\mathrm{MP}_{1000}$-LPX NP 5 was examined by transmission electron microscopy (TEM, H-600, Hitachi, Japan). Briefly, $100 \mu \mathrm{L}$ of $\mathrm{MP}_{1000}$-LPX suspension was added onto copper electron microscopy grids. Subsequently, they were negatively stained with $2 \%$ phosphotungstic acid for observation.

\section{Gel Electrophoresis Retardation Assay}

To evaluate the complexation of mRNA and MP 1000 -LPs, $1 \mu \mathrm{g}$ free mRNA and $\mathrm{MP}_{1000}$-LPX (containing $1 \mu \mathrm{g}$ mRNA) were diluted with RNase-free water. Then NorthernMax ${ }^{\circledR}$ formaldehyde load dye containing ethidium bromide $(50 \mu \mathrm{g} / \mathrm{mL})$ was added and mixed. After incubating the samples for $10 \mathrm{~min}$ in $65^{\circ} \mathrm{C}$, the samples were loaded into a $1 \%$ denaturing formaldehyde agarose gel in precooled MOPS buffer. The gel was run for $20 \mathrm{~min}$ at $180 \mathrm{~V}$ and analyzed using a molecular imager, ChemiDocTM 219 XRS system (Bio-Rad, United States). RNA Millennium ${ }^{\mathrm{TM}}$ markers (Ambion) with bands at a range of 0.5-9 $\mathrm{kb}$ was included to provide size determination of the mRNA.

\section{Stability Assay}

For storage stability experiments, prepared $\mathrm{MP}_{\mathrm{n}}$-LPX NP 5 were stored at $4^{\circ} \mathrm{C}$ for 1 and 3 days and another $1 \mathrm{~h}$ at $\mathrm{rt}$ before particle size and transfection efficiency measurement following the similar procedure described previously (Kranz et al., 2016).

To evaluate the serum stability, $1 \mu \mathrm{g}$ free mRNA and $\mathrm{MP}_{\mathrm{n}}$-LPX NP 5 (containing $1 \mu \mathrm{g}$ mRNA) were incubated in parallel with $150 \mathrm{mM} \mathrm{NaCl}$ supplemented with or without FBS at $50 \%$ final concentration at $37^{\circ} \mathrm{C}$ for $2 \mathrm{~h}$, respectively. To release mRNA from LPX, $1 \mu \mathrm{L}$ of $10 \%$ Triton X-100 was added to $10 \mu \mathrm{L}$ of $\mathrm{MP}_{1000}$-LPX samples and incubated at rt for $10 \mathrm{~min}$. After mixed with NorthernMax ${ }^{\circledR}$ formaldehyde load dye, samples were treated and visualized using the similar process as described in Section "Gel Electrophoresis Retardation Assay."

\section{Cytotoxicity Assay}

To test potential cytotoxicity, DC2.4 cells were treated with $\mathrm{MP}_{1000}$-LPX according to the transfection procedure. Cell viability was investigated using an Apoptosis Detection Kit according to the manufacturer's protocol by flow cytometry. Three independent cytotoxicity assays were performed in duplicate.

\section{Cellular Uptake of MP-LPX}

Cellular uptake study was performed using Cou- 6 as previously reported (Xu et al., 2016). DC2.4 cells in the logarithmic growth period were collected and seeded at a density of $8 \times 10^{5}$ cells/well in a 24 -well plate and incubated for $24 \mathrm{~h}$ at $37^{\circ} \mathrm{C}$. To screen the appropriate incubation time, DC2.4 cells were treated with LPX (Cou-6, $5 \mathrm{ng} / \mathrm{mL}$ ) in triplicate by different time from $0.5 \mathrm{~h}$ to $6 \mathrm{~h}$. At the end of the study, the cells were collected and washed three times with cold phosphate buffer saline. The MFI of cells was quantified by BD FACS. To further screen the uptake concentration of Cou-6, DC2.4 cells were treated in triplicate by different concentrations of Cou- 6 from $2.5 \mu \mathrm{g} / \mathrm{mL}$ to $20 \mu \mathrm{g} / \mathrm{mL}$ for $2 \mathrm{~h}$.

To investigate the MR mediate uptake of $\mathrm{MP}_{1000}$-LPX (Cou-6, $10 \mathrm{ng} / \mathrm{mL}$ ), DC2.4 cells were pre-treated with or without $0.16 \mathrm{~mol} / \mathrm{L}$ of mannose solution for $30 \mathrm{~min}$ followed by incubation with LPX and $\mathrm{MP}_{1000}-\mathrm{LPX}$ at $37^{\circ} \mathrm{C}$, respectively. For binding assays, DC2.4 cells were incubated at $4^{\circ} \mathrm{C}$ for $30 \mathrm{~min}$. Subsequently, LPX and MP 1000 -LPX were added and incubated for $2 \mathrm{~h}$ at $4^{\circ} \mathrm{C}$.

\section{Statistical Analysis}

The data were presented as mean \pm SEM unless otherwise noted. Statistical analysis was performed using Graphpad Prism 5.0. Data of two or multiple groups were analyzed using Student's $t$-test or non-parametric one-way ANOVA, respectively. The $p$-values $<0.05$ were considered statistically significant.

\section{RESULTS}

\section{Characterization of $\mathrm{MP}_{\mathrm{n}}-\mathrm{CH}$ Characterization of $\mathrm{MP}_{100}-\mathrm{CH}$}

We construct $\mathrm{MP}_{100}-\mathrm{CH}$ (compound 6) according to reasonable design as shown in Figure 1A. The structure of compounds 1, 2, 3, 4, and 5 were validated in Supplementary Figures S1-S5, respectively. As shown in Figure $\mathbf{2 A}$, the ${ }^{1} \mathrm{H}$ NMR spectra of compounds 4, 5 and $\mathbf{6}$ were recorded. The single peaks at $\delta 5.33$ (s) were attributed to the protons of olefinic bond $\left(-\mathrm{CH}_{2}-\mathrm{CH}=\mathrm{C}-\right)$ in cholesterol. The single peak at $\delta 8.01$ (s) came from the protons of olefinic bond (N-CH $=\mathrm{C}-\mathrm{N})$ in coupled places. The peaks at $\delta 3.15-3.88(\mathrm{~m})$ were attributed to the protons from the glycol unit $\left(-\mathrm{O}-\mathrm{CH}_{2}-\mathrm{CH}_{2}-\mathrm{O}-\mathrm{CH}_{2-}\right)$ in PEG chain. These results indicated that $\mathrm{MP}_{100}-\mathrm{CH}$ has been successfully synthesized. As seen in Figure 2B, the mass spectrum of $\mathrm{MP}_{100}-\mathrm{CH}$ showed a peak at 740.49 (product $+\mathrm{Na}^{+}$), which was consistent with the expected molecular weight of $\mathrm{MP}_{100}-\mathrm{CH}$. In addition, compound 6 was further confirmed by FTIR spectroscopy with of the following principal peaks: $\nu-\mathrm{OH}\left(3700-3400 \mathrm{~cm}^{-1}\right), \nu-\mathrm{CH}_{3}$ and $\nu-\mathrm{CH}_{2}$ (2960-2850 $\left.\mathrm{cm}^{-1}\right), \nu-\mathrm{CH}_{2}-\mathrm{O}-\mathrm{CH}_{2}-\left(1210-1050 \mathrm{~cm}^{-1}\right)$ presence but $\nu-\mathrm{N}=\mathrm{N}-\mathrm{N}-\left(2100-2270 \mathrm{~cm}^{-1}\right)$ attributed to compound 4 , $\nu$ - $\mathrm{CH}$ (about $3300 \mathrm{~cm}^{-1}$ ) attributed to compound 5 absence in compounds 6 (Figure 2C). Finally, as shown in Figure 2D, the spectrum of HPLC exhibited a characteristics absorption peak of $\mathrm{MP}_{100}-\mathrm{CH}$ at $9.743 \mathrm{~min}(201 \mathrm{~nm})$. According to the method of area normalization, the purity of $\mathrm{MP}_{100}-\mathrm{CH}$ is $97.948 \%$. 


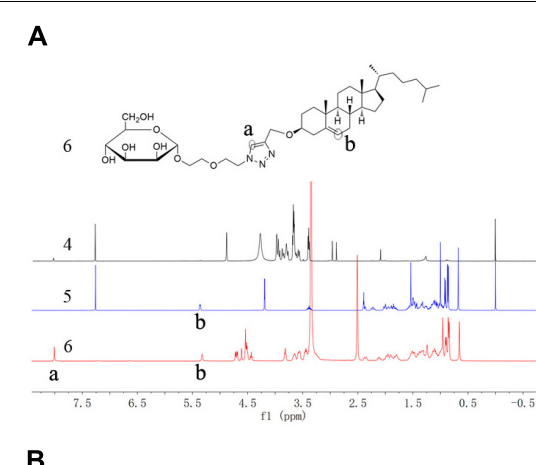

B

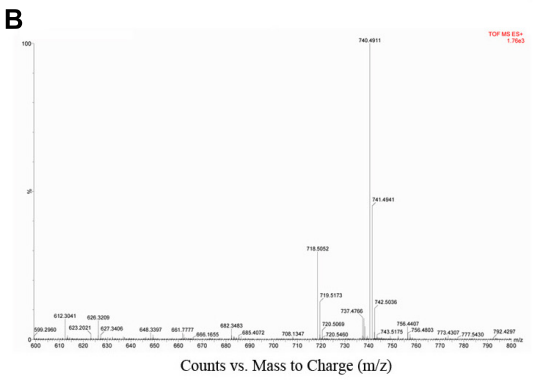

C

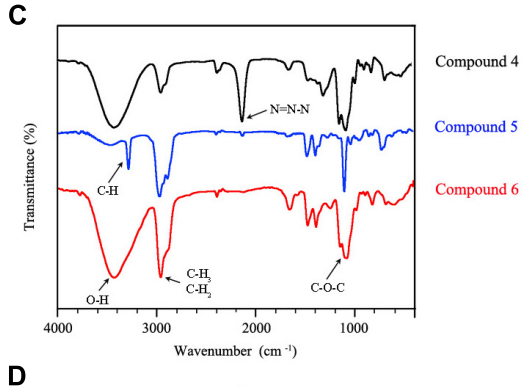

D

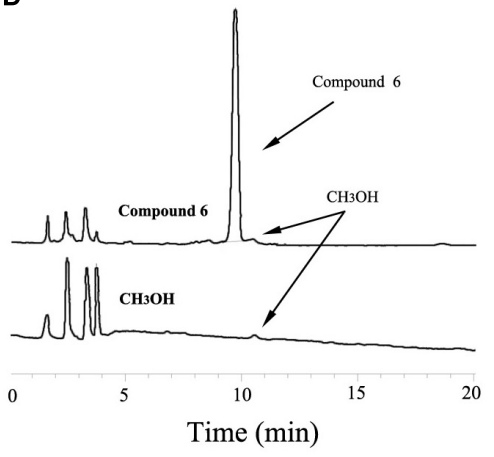

E

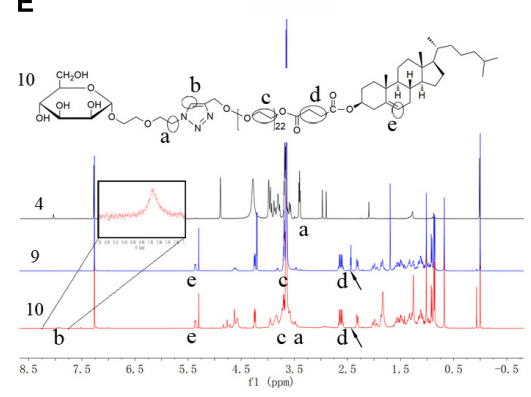

$\mathbf{F}$

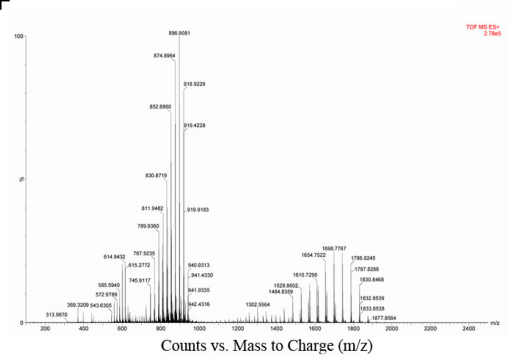

G

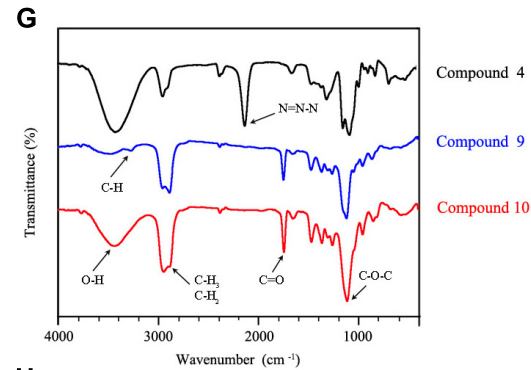

H

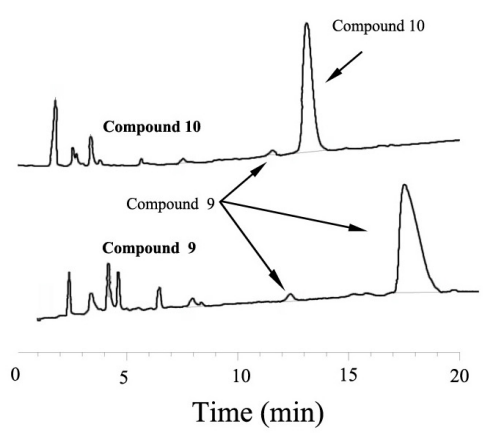

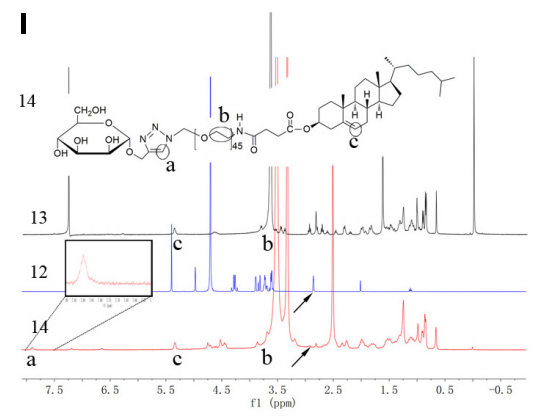

J

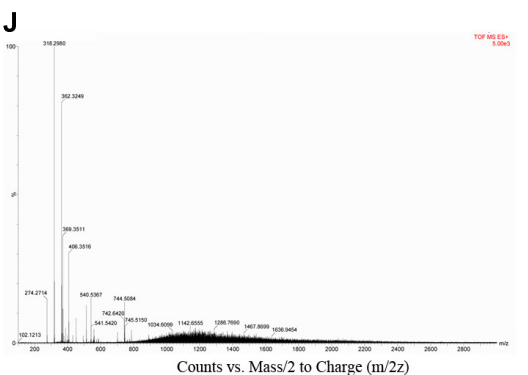

K

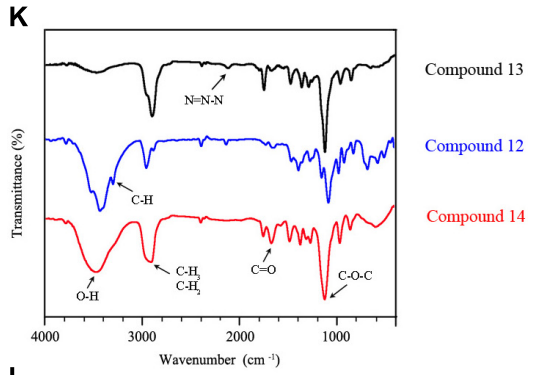

L

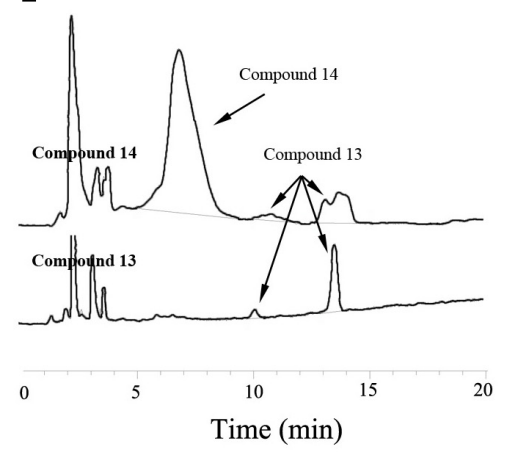

FIGURE 2 | Characterization of $\mathrm{MP}_{\mathrm{n}}-\mathrm{CHs}$. (A) Comparison of the ${ }^{1} \mathrm{H} \mathrm{NMR}$ spectra of compounds $\mathbf{4}, \mathbf{5}$, and $\mathbf{6}$. The protons of olefinic bond ( $\left.\mathrm{N}-\mathrm{CH}=\mathrm{C}-\mathrm{N}\right)$ in coupled places were shown in compounds 6. (B) Mass spectrum of $\mathrm{MP}_{100}-\mathrm{CH}$ was shown as $(\mathrm{M}+\mathrm{Na})^{+}, \mathrm{m} / \mathrm{z}$ : 740.4911 . (C) FTIR spectrum of compounds 4, 5, and 6. (D) High purity (97.984\%) of $\mathrm{MP}_{100}-\mathrm{CH}$ was confirmed using HPLC. (E) Comparison of the ${ }^{1} \mathrm{H}$ NMR spectra of compounds $\mathbf{4}$, 9, and $\mathbf{1 0}$ in $\mathrm{CDCl}$. (F) Mass spectrum of compounds 10 was shown as $(\mathrm{M}+\mathrm{Na})^{+}, \mathrm{m} / \mathrm{Z}$ : 1484.8359 to 1830.8468 . (G) FTIR spectrum of compounds $\mathbf{4}$, 9, and 10. (H) HPLC spectra was used to evaluate the purity of $\mathrm{MP}_{1000}-\mathrm{CH}(95.621 \%) .{ }^{1} \mathrm{H}$ NMR spectra (I) and FTIR spectrum (K) of compounds 12, 13, and 14. (J) Mass spectrum of MP $2000-\mathrm{CH}$ was shown as $(\mathrm{M} / 2+\mathrm{Na})^{+}, \mathrm{m} / \mathrm{z}$. (L) The purity of $\mathrm{MP}_{2000}-\mathrm{CH}$ was evaluated $(91.532 \%)$.

\section{Characterization of $\mathrm{MP}_{1000}-\mathrm{CH}$}

To construct $\mathrm{MP}_{1000}-\mathrm{CH}$ (compound 10), compound 4 was jointed to compound 9 via click reaction as shown in Figure 1B. The structure of compounds $\mathbf{8}$ and $\mathbf{9}$ were firstly confirmed in Supplementary Figures S6, S7, respectively. The ${ }^{1} \mathrm{H}$ NMR spectra of compounds $\mathbf{4 , 9}$ and 10 were recorded in $\mathrm{CDCl}_{3}$. The principal proton peaks at $82.42-2.45(\mathrm{t})$ attributed to the protons of alkynyl group (-CH) in compounds 9 were disappeared in compounds 10 as in shown Figure 2E. Similar to $\mathrm{MP}_{100}-\mathrm{Chol}$ (presence of single peak at 88.01 ), the successful synthesis of $\mathrm{MP}_{1000}$-Chol has also been validated. The mass spectrum of $\mathrm{MP}_{1000}$-Chol showed broad peaks from 1484.8359 to 1830.8468 (Figure 2F) while that of compound 9 were from 1185.8085 to 1480.0358 (Supplementary Figure S8). The increased molecular 
weight coincided with the molecular weight of compounds 4, which also confirmed the structure of compound 10 referring to previously report (Li et al., 2014). The FIIR spectroscopy of compounds 10 (Figure 2G) was similar to compounds 4 but the presence of unique $\nu$ - $\mathrm{CH}_{2}-\mathrm{CO}-\mathrm{O}$ - of compounds 10 at around $1740 \mathrm{~cm}^{-1}$. Additionally, the characteristics absorption peak $(201 \mathrm{~nm})$ of compounds $\mathbf{1 0}$ and compounds $\mathbf{9}$ were at $13.122 \mathrm{~min}$ with the purity of $96.595 \%$ (Figure $2 \mathbf{H}$ ) and $16.692 \mathrm{~min}$ with the purity of $94.881 \%$, respectively. Consistent with expectation, the hydrophilicity of compound 10 was increased and the retention time was decreased when compared with compound 9. All of the results of ${ }^{1} \mathrm{H}$ NMR spectra, mass spectrum, FTIR spectroscopy and HPLC confirmed the successful synthesis of compounds $\mathbf{1 0 .}$

\section{Characterization of $\mathrm{MP}_{2000}-\mathrm{CH}$}

Similar to compound 10, compound $\mathbf{1 4}$ was acquired according to our designed strategies (Figure 1C) and authenticated via ${ }^{1} \mathrm{H}-\mathrm{NMR}$ (Figure 2I), electrospray ionization mass spectrometry (ESI-MS) (Figure 2J), FTIR (Figure 2K), and HPLC (Figure 2L). The structure of compounds $\mathbf{1 1}$ and $\mathbf{1 2}$ were firstly confirmed in Supplementary Figures S9, S10, respectively. Of note, the measured molecular weight of compound $\mathbf{1 2}$ was 241.07 (product $+\mathrm{Na}^{+}$) (Supplementary Figure S11), which was consistent with the expected molecular weight. When compared mass spectrum of compound 14 (Figure 2J) with compound 13 (Supplementary Figure S12), nearly 200 molecular weight were increased. The retention time at $201 \mathrm{~nm}$ of compound 14 and compound 13 were at $6.907 \mathrm{~min}$ with the purity of $91.532 \%$ and $13.662 \mathrm{~min}$ with the purity of $91.251 \%$ (Figure $2 \mathrm{~L}$ ), respectively.

\section{Particle Size and Zeta Potential Measurement}

The size and zeta potential of all formulations in this study were evaluated. There was no statistical difference between the particle size and zeta potential among different $\mathrm{MP}_{\mathrm{n}}-\mathrm{LPs}$ or $\mathrm{MP}_{\mathrm{n}} \mathrm{LPX}$ formulations. The particle size and zeta potential of all different $\mathrm{MP}_{\mathrm{n}}$-LPs was about $60 \mathrm{~nm}$ (Figure 3A) and $50 \mathrm{mV}$ (Figure 3B), respectively. In addition, the particle size and zeta potential of all different LPX was about $135 \mathrm{~nm}$ (Figure 3C) and $40 \mathrm{mV}$ (Figure 3D), respectively. The PDI were all less than 0.3. As was shown, the size of $\mathrm{MP}_{\mathrm{n}}-\mathrm{LPX}$ was larger and the zeta potential was lower than the corresponding $\mathrm{MP}_{\mathrm{n}}$-LPs formulations.

\section{In vitro Transfection of $\mathrm{MP}_{\mathbf{n}}-\mathrm{LPX}$}

To investigate the in vitro transfection efficacy of $\mathrm{MP}_{\mathrm{n}}$ LPX in DC2.4 cells, the appropriate ratio of N/P of LPX was optimized firstly. GFP expression on DC2.4 cells with different treatment were observed and recorded by fluorescence microscope (Supplementary Figures S13A-H). As shown in Supplementary Figure S13I, both LPX NP 7 and LPX NP 5 achieved significant increment in transfection efficiency compared with LPX NP 3. What's more, LPX NP 5 with similar transfection efficiency to LPX NP 7 exhibited dramatically enhanced GFP fluorescence intensity (mean GFP expression level per cell) (Supplementary Figure S13J). By the way, calculation of MFI and GFP positive cells was shown in Supplementary Figure S14. Thus, $\mathrm{MP}_{\mathrm{n}}-\mathrm{LPX}$ were prepared by setting the N/P ratio at 5:1. The GFP expression was subsequently observed by fluorescence microscope (Figure 4A). As shown in Figure 4B, $\mathrm{MP}_{1000}-\mathrm{LPX}$ induced the most GFP positive cells and the
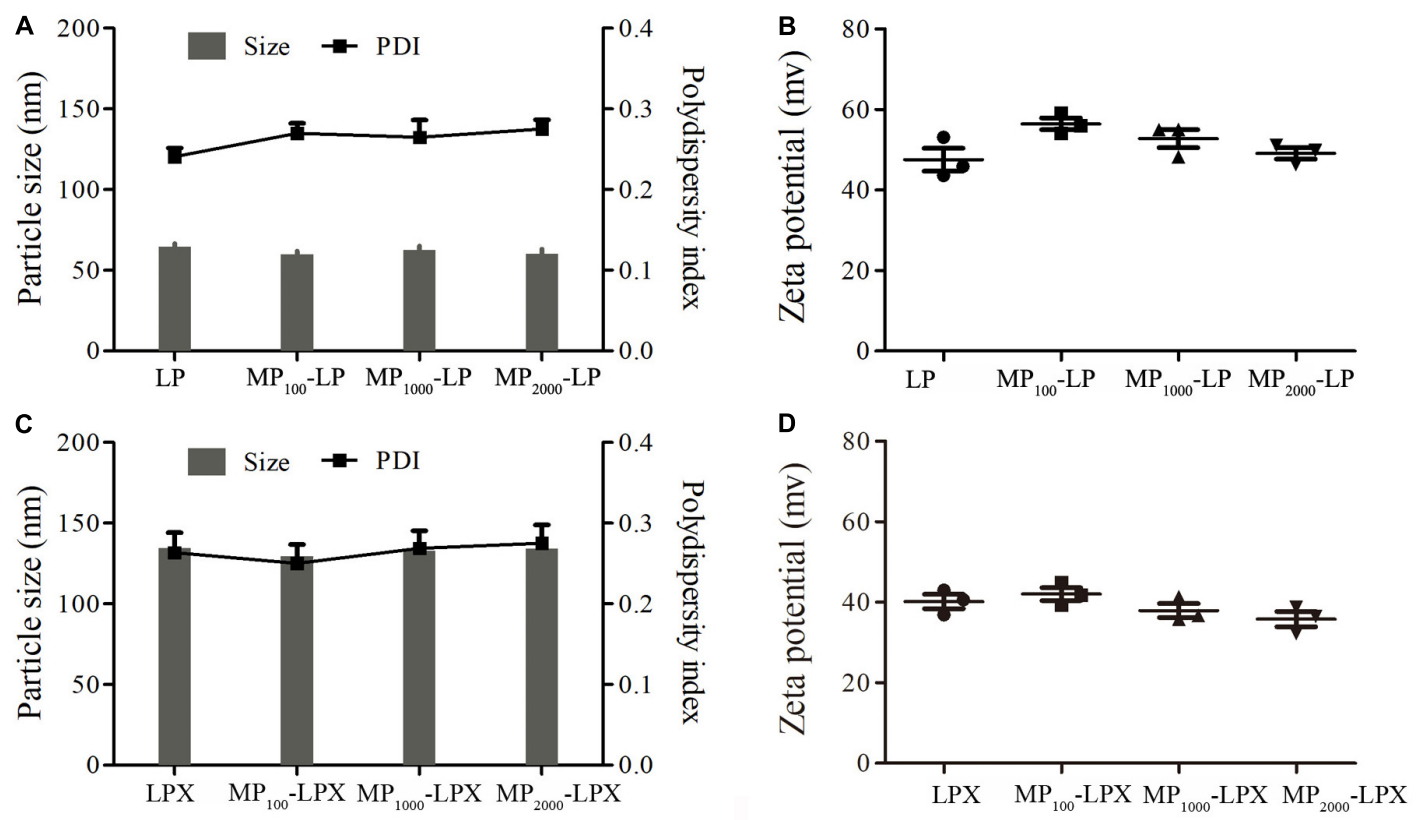

FIGURE 3 | Physicochemical properties of $M_{n}-L P s$ and $M P_{n}-L P X$. Size (A) and zeta potential (B) of MP ${ }_{n}$-LPs with different PEG linkers. Size (C) and zeta potential (D) of different formulations loaded with mRNA. 


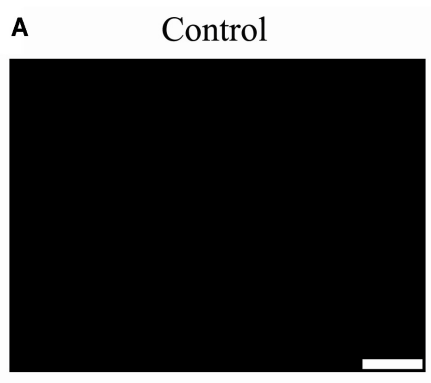

$\mathrm{MP}_{100}-\mathrm{LPX}$

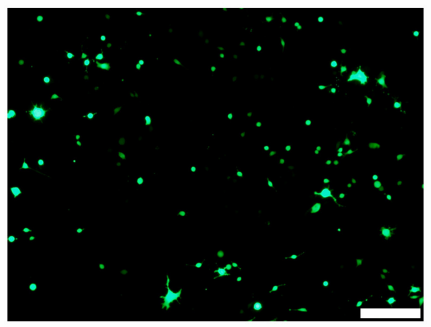

$\mathrm{MP}_{2000}-\mathrm{LPX}$

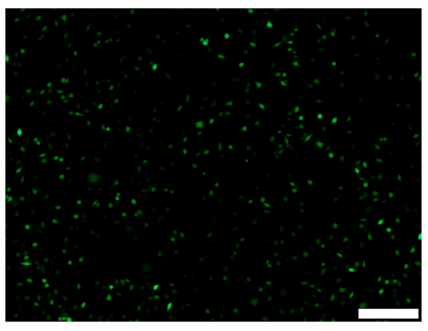

D

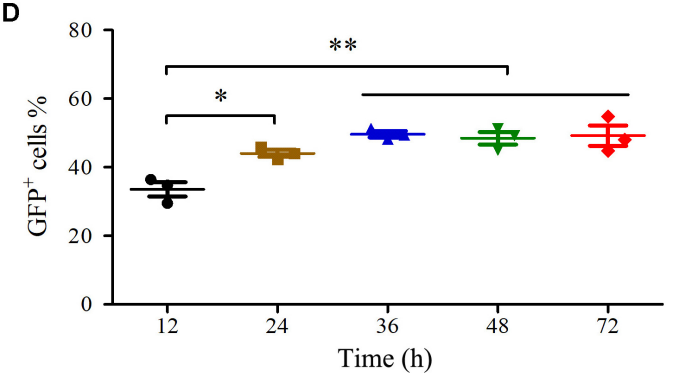

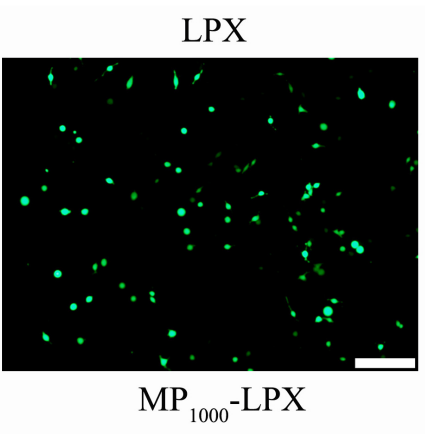

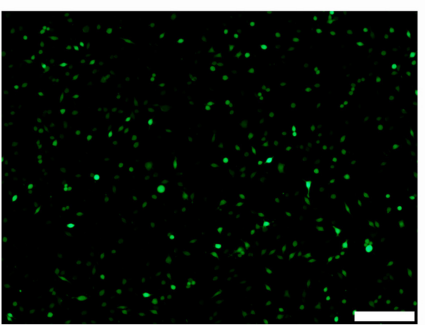

Lipo 3K

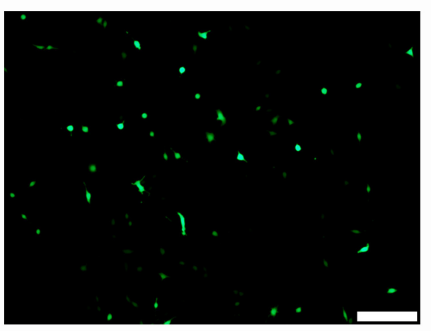

B
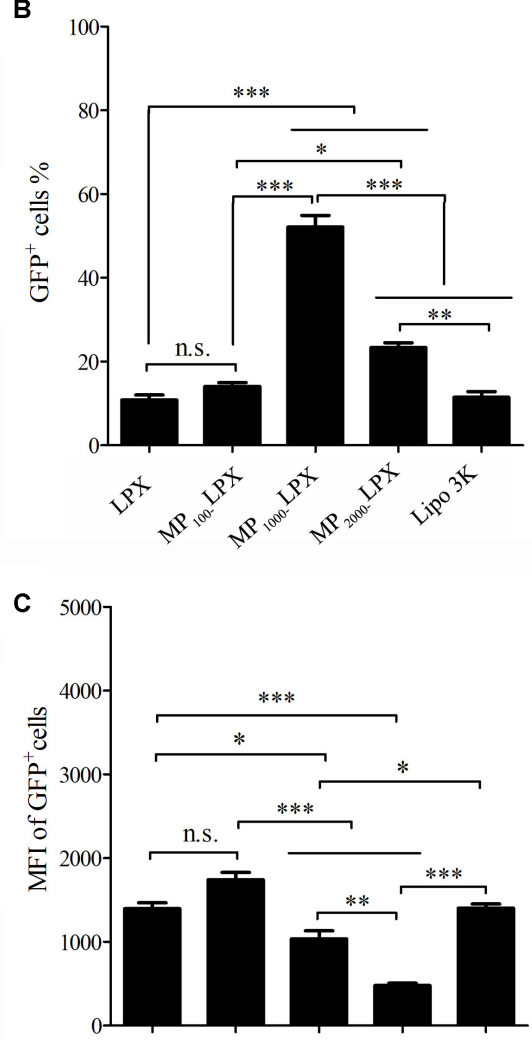

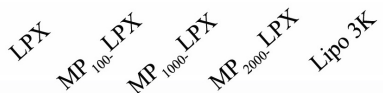

E

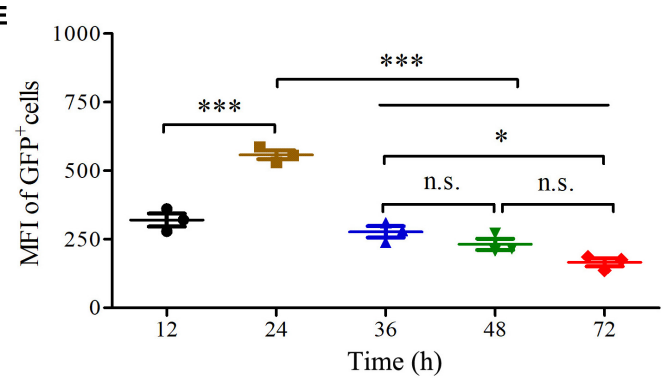

FIGURE 4 | Transfection of MP $\mathrm{n}_{\mathrm{n}}$-LPX with different PEGs length on DC2.4 cells at N/P 5. (A) GFP expression by DC2.4 cells observed by a fluorescence microscope. Transfection efficiency (\%GFP ${ }^{+}$cells) (B) and MFI of GFP ${ }^{+}$cells (C) were quantified. Kinetics of MP $1000-\mathrm{LPX}$ NP 5 transfection efficiency (D) and MFI of GFP positive cells (E) on DC2.4 cells from $12 \mathrm{~h}$ to $72 \mathrm{~h}$. Scale bars, $200 \mu \mathrm{m} .{ }^{*} p<0.05 ;{ }^{* *} p<0.01 ;{ }^{* * *} p<0.001$.

percentage was up to $52 \%$, which was significantly higher than any other groups $(p<0.001)$. However, the MFI of the GFP positive cells of $\mathrm{MP}_{1000}$-LPX NP 5 was not the best among these groups (Figure 4C). Taking into account of transfection efficiency and MFI, MP 1000 -LPX with the highest transfection efficiency and moderate MFI were selected for further study in this manuscript.

The kinetics of $\mathrm{MP}_{1000}$-LPX NP 5 transfection on DC2.4 cells was studied. As shown in Figures 4D,E, transfection efficiency first increased and then reached a plateau with the increase of the incubation time (from 12 to $72 \mathrm{~h}$ ) while the MFI of GFP positive cells first increased and then decreased. In summary, the transfection efficiency achieved the maximum at $24 \mathrm{~h}$ and MFI was also the strongest at $24 \mathrm{~h}$.

\section{Further Study on the Optimal MP $_{1000}$-LPX Morphology Examination}

The appearance and morphological studies of $\mathrm{MP}_{1000}$-LPX were conducted. The colloidal solution was colorless and transparent (Figure 5A). Overt Tyndall effect of $\mathrm{MP}_{1000}$-LPs and $\mathrm{MP}_{1000}$-LPX colloidal solution were observed compared with water as was shown in Figure 5B. Representative images of size and 
zeta potential of $\mathrm{MP}_{1000}-\mathrm{LP}(\mathrm{X})$ were shown in Figures $5 \mathrm{C}-\mathrm{F}$, respectively. As shown in Figure 5G, the morphological of $\mathrm{MP}_{1000}$-LPX was observed distinct lipid membrane structure with nearly spherical in shape. Moreover, complete complexation of the mRNA with $\mathrm{MP}_{1000}$-LPs was confirmed when the N/P ratio of 3 and 5 (Figure $5 \mathbf{H}$ ).

\section{Stability Assessment}

The preliminary storage stability of the $\mathrm{MP}_{1000}$-LPX was determined by the size, zeta potential and transfection efficiency. The particle size and zeta potential of $\mathrm{MP}_{1000}$-LPX were determined at predetermined time of storage at $4^{\circ} \mathrm{C} . \mathrm{MP}_{1000}$-LPX displayed a little decrease in particle size but not zeta potential (Figure 6A) As shown in Figure 6B, the transfection efficiency of $\mathrm{MP}_{1000}$-LPX remained about $50 \%$ when stored at $4^{\circ} \mathrm{C}$ for 3 days. Additionally, $\mathrm{MP}_{100}$-LPX (Supplementary Figure S15A) and $\mathrm{MP}_{2000}$-LPX (Supplementary Figure S15B) performed excellent storage stability in the preliminary test.

For serum stability, $5 \mu \mathrm{L}$ of fresh $\mathrm{MP}_{1000}$-LPX were diluted in $\operatorname{FBS}(1: 1, \mathrm{v} / \mathrm{v})$ and incubated for $2 \mathrm{~h}$ at $37^{\circ} \mathrm{C}$. As shown in Figure 6C, the signal of naked mRNA band in serum was completely disappeared (lane 3) compared to naked mRNA alone (lane 1). $\mathrm{MP}_{1000}$-LPX did not dissociate after incubation in $50 \%$ serum (lane 5) similar to that incubation in $\mathrm{NaCl}$ of $150 \mathrm{mM}$ (lane 4). When the free mRNA or $\mathrm{MP}_{1000}$-LPX were treated with Triton X-100, the free mRNA (lane 2) and mRNA dissociated from $\mathrm{MP}_{1000}$-LPX (lane 4) were visible in line with mRNA treated without Triton X-100 (lane 1) as shown in Figure 6D. Similarly, $\mathrm{MP}_{100}$-LPX and $\mathrm{MP}_{2000}$-LPX exerted good stability in the presence of serum (Supplementary Figure S15C). These results confirmed the adequate protection of the mRNA against degradation.

\section{Cytotoxicity Assay}

After incubation with indicated formulations for $24 \mathrm{~h}$, cytotoxicity analysis was performed by flow cytometry. Representative figure of each condition was showed in Figure 7A. The percentage of living DC2.4 cells were found to be $86.7 \pm 3.6$ $\%, 86.4 \pm 1.7 \%$, and $90.1 \pm 1.2 \%$ (Figure $7 \mathbf{B}$ ) for control (treated with equal volume of medium), MP 1000 -LPX and Lipo $3 \mathrm{~K}$ group, respectively. None significant percentage difference of living cells, early apoptosis, late apoptosis or necrosis was found among these three groups indicating that $\mathrm{MP}_{1000}-\mathrm{LPX}$ might do no harm to DC2.4 cells. Overall, $\mathrm{MP}_{1000}$-LPX NP 5 performed good safety in vitro. Considering the excellent transfection efficacy, $\mathrm{MP}_{1000}$-LPX might be one of good candidates for DC-targeting mRNA nanovaccine for in vivo application.

\section{In vitro Uptake}

In the preliminary uptake experiment, incubation time and concentration of Cou- 6 were optimized. According to the results in Supplementary Figures S16A,B, $2 \mathrm{~h}$ and $10 \mathrm{ng} / \mathrm{mL}$ were selected for future cellular uptake experiment, respectively. To evaluate the potency of MP 1000 -LPX NP 5 on targeted delivery into DC2.4 cells, the fluorescent of Cou- 6 internalized by cells was assayed by BD FACS. The results in Figure 7C indicated that intracellular uptake of $\mathrm{MP}_{1000}$-LPX was significantly higher than that of LPX at 37 and $4^{\circ} \mathrm{C}$, respectively. When pretreated the cells with mannose, no significant difference of Cou- 6 in cellular uptake between MP 1000 -LPX and LPX was observed. Moreover, intracellular uptake of LPX and $\mathrm{MP}_{1000}$-LPX was significantly lower at $4^{\circ} \mathrm{C}$ than that at $37^{\circ} \mathrm{C}$, indicating that uptake of LPs loaded with mRNA was energy dependent.

\section{DISCUSSION}

In the presented study, we designed facile and inexpensive approach to prepare mannose-cholesterol conjugates with various linker length as synthetic ligands applied to mRNA nanovaccine. $\mathrm{MP}_{\mathrm{n}}$-LPs were prepared by a modified thin-film dispersion method. Subsequently, the DCs targeting $\mathrm{MP}_{\mathrm{n}}-\mathrm{LPX}$ were prepared by complexing $\mathrm{MP}_{\mathrm{n}}$-LPs with mRNA. No significant difference in size and zeta potential was observed among $\mathrm{MP}_{\mathrm{n}}$-LPX comprised $\mathrm{MP}_{\mathrm{n}}-\mathrm{CH}$ with different PEG units. The effect of linker length of mannose derivatives in $\mathrm{MP}_{\mathrm{n}}-\mathrm{LPX}$ on transfection by DC2.4 cells was investigated. Our results might provide a rational design element of mRNA vaccine.

Linker length of ligand exerted significantly effect on targeting cellular uptake (Engel et al., 2003; Stefanick et al., 2013; Jeong et al., 2014). Thus, a proper linker length of the ligands was essential for effective receptor recognize and binding. For recognition and binding to $\mathrm{MR}$, linker length of mannose should consist of at least two PEG units according to previously report (Jeong et al., 2014). In our study, mannose-cholesterol conjugates with different linker length were designed and constructed by facile strategies utilizing the click reaction. In detail, mannose derivatives have been conjugated to cholesterol derivatives modified with PEG of different lengths $\left(\mathrm{PEG}_{100}\right.$, $\mathrm{PEG}_{1000}$, or $\mathrm{PEG}_{2000}$ ). Each target product was fully characterized by ${ }^{1} \mathrm{H}$-NMR, ESI-MS, FTIR to confirm the successful of synthesis. HPLC was used to evaluate the purity and the successful synthesis of the products as previously reported (Shariat et al., 2014). The synthetic strategies designed here offered some overt advantages over the previously reported methods for Man- $\mathrm{C}_{4}$-chol (Kawakami et al., 2000) and Man- $\mathrm{C}_{6}$-chol (Li et al., 2013), because our target products were easily to synthesis, purify and characterize. What's more, the length of PEG-linkers could be varied with desired length, resulting in many other analogous compounds with MR targeting function.

We constructed $\mathrm{MP}_{\mathrm{n}}$-LPs with various linker lengths between cholesterol and mannose using different length of PEG linker. All $\mathrm{MP}_{\mathrm{n}}$-LPs were constructed with the same molar ratio of mannose modified cholesterol. The $\mathrm{MP}_{\mathrm{n}}$-LPs had similar average size and surface charge despite of the introduction of $\mathrm{MP}_{\mathrm{n}}$ $\mathrm{CHs}$ with different linker lengths of PEG. We then prepared $\mathrm{MP}_{\mathrm{n}}$-LPX and performed cellular transfection studies in DC2.4 cells with the evaluated parameters of transfection efficiency and MFI of GFP positive cells, respectively. Transfection efficiency and MFI of LPX was preliminary optimized to find optimal ratio of $\mathrm{N} / \mathrm{P}$. Our results showed no significant difference in transfection efficiency of LPX NP 5 and LPX NP 7, while both exhibited significantly higher transfection efficiency than LPX NP 3. However, MFI of the GFP positive cells of LPX NP 5 


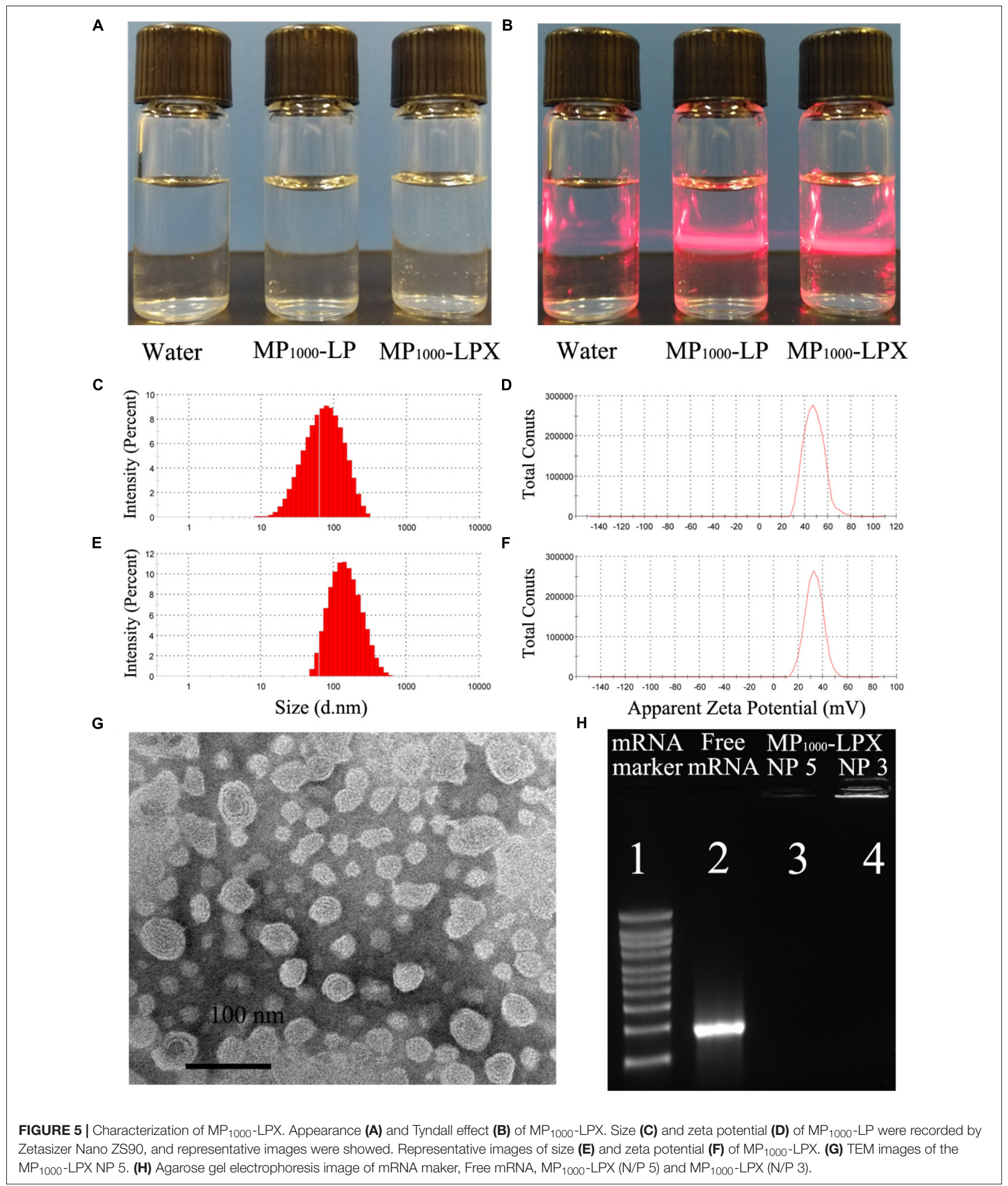

was significantly higher compared to that of LPX NP 7. Taken the transfection efficiency and MFI of the GFP positive cells into consideration, the ratio of $\mathrm{N} / \mathrm{P}$ of 5 was selected for future studies. The difference between the percentage of transfected cells and the MFI of transfected cells was consistent with previously reported results (McLenachan et al., 2013; Avci-Adali et al., 2014; 


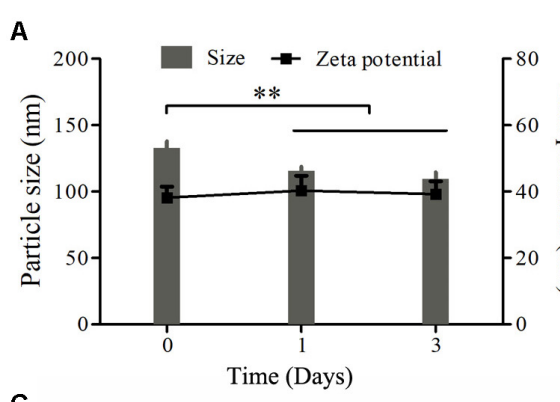

B
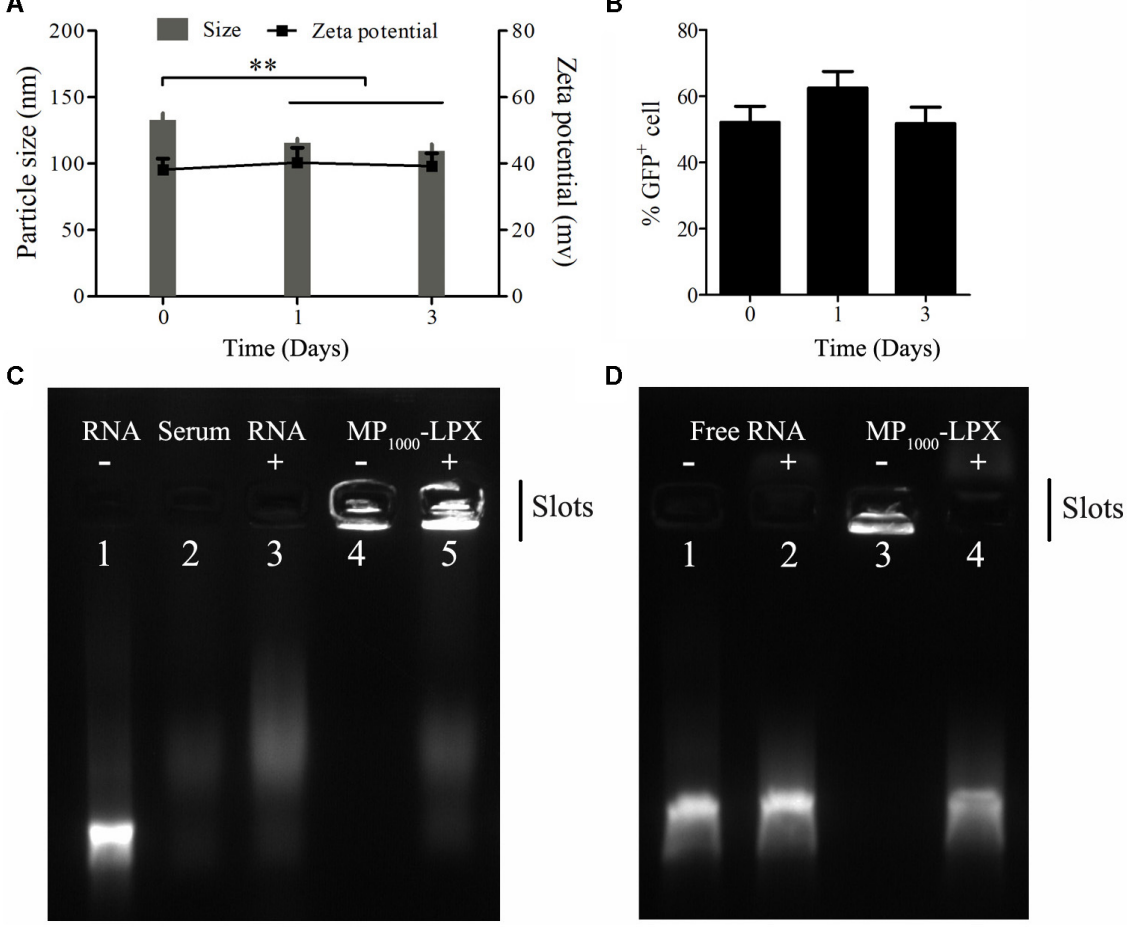

FIGURE 6 | Stability of MP 1000 -LPX. (A) Size and zeta potential measurements of MP 1000 -LPX at 0, 1, and 3 days stored at $4{ }^{\circ} \mathrm{C}$. (B) Transfection efficiency of $\mathrm{MP}_{1000}$-LPX at 0,1 , and 3 days stored at $4^{\circ} \mathrm{C}$. (C,D) Gel electrophoresis retardation assay of MP $1000-\mathrm{LPX}(\mathrm{N} / \mathrm{P}: 5: 1)$ to test serum stability. (C) Free RNA (lane 1), Serum (lane 2), Serum + RNA (lane 3), MP1000-LPX (lane 4) and Serum + MP1000-LPX (lane 5). (D) Free RNA in 150 mM NaCl treated without (lane 1) or with Triton X-100 (lane 2). MP1000-LPX in $150 \mathrm{mM} \mathrm{NaCl}$ treated without (lane 3) and or with Triton X-100 (lane 4). **p < 0.01.

Lee et al., 2015; Li et al., 2017a). Transfection using the same transfection reagent led to similar transfection efficiency but not the MFI (Figures 4D,E) with the increase of the incubation time, which was consistent with previously report (Avci-Adali et al., 2014). In addition, increasing the amount of mRNA can significantly increase the average fluorescence intensity without affecting the transfection efficiency within a certain range (AvciAdali et al., 2014). Moreover, MFI values showed the strength of the fluorescence intensity. Higher MFI values reflected a higher production of GFP by individual cell but not higher percentage of GFP positive cells.

According to literatures, upon interaction with serum, nanocarriers rapidly absorbed protein and formed a corona (Bertrand et al., 2017; Pan et al., 2017). It was the nanocarrier-corona complex, rather than the nanocarrier, that interacted with biological systems, here with a cell membrane receptor (CD206), which might partially obscure the role of target ligands (Monopoli et al., 2012). To reduce this effect, culture medium without serum was used at initial and complete culture medium with serum were added $4 \mathrm{~h}$ after the adding of LPX. As was known, the fate of nano-preparations in serum (mimic the in vivo environment) was very important to predict its potential therapeutic efficacy. Our preliminary test showed that the presence serum significantly affected the transfection of $\mathrm{MP}_{1000}$-LPX. We were still working on this. Hopefully, we would show the data of mRNA delivery in the presence of serum in vitro and expression of the nano-preparations in vivo in our future work.

$\mathrm{MP}_{1000}$-LPX exhibited a higher level of transfection efficiency than LPX, MP $100-\mathrm{LPX}, \mathrm{MP}_{2000}$-LPX and positive control Lipo $3 \mathrm{~K}$. No size and charge variation were found in the vectors then no inference can be made on the transfection efficiency correlation with size and charge. The excellent transfection efficiency of $\mathrm{MP}_{1000} \mathrm{LPX}$ was most likely attributed to the appropriate linker length used to conjugate mannose and cholesterol. However, $\mathrm{MP}_{1000} \mathrm{LPX}$ exerted the highest transfection efficiency but moderate MFI. The inconsistency of cellular transfection efficiency and MFI observed in the field of targeted mannose modified LPX partially resulted from differences in the types of cell, incubation time, the amount of mRNA, ability of lysosome escape and types of lipid mannose modified (Kim et al., 2012; Li et al., 2013; Avci-Adali et al., 2014; Chen et al., 2015; Wang C. et al., 2015). The best effect of $\mathrm{MP}_{1000}$-LPs conjugates may be related to the above factors. However, most likely it was attributed to the linkers used to conjugate mannose and the other different component of targeting formulations (Kim et al., 2012; Wang N. et al., 2014; Wang C. et al., 2015). There are many other known and unknown factors for ligand receptor affinity beside linker length of ligand. Moreover, the intracellular metabolism of mRNA nanovaccine might also affect the expression of protein encoded by mRNA. Accurately, we cannot declare that the linker length 

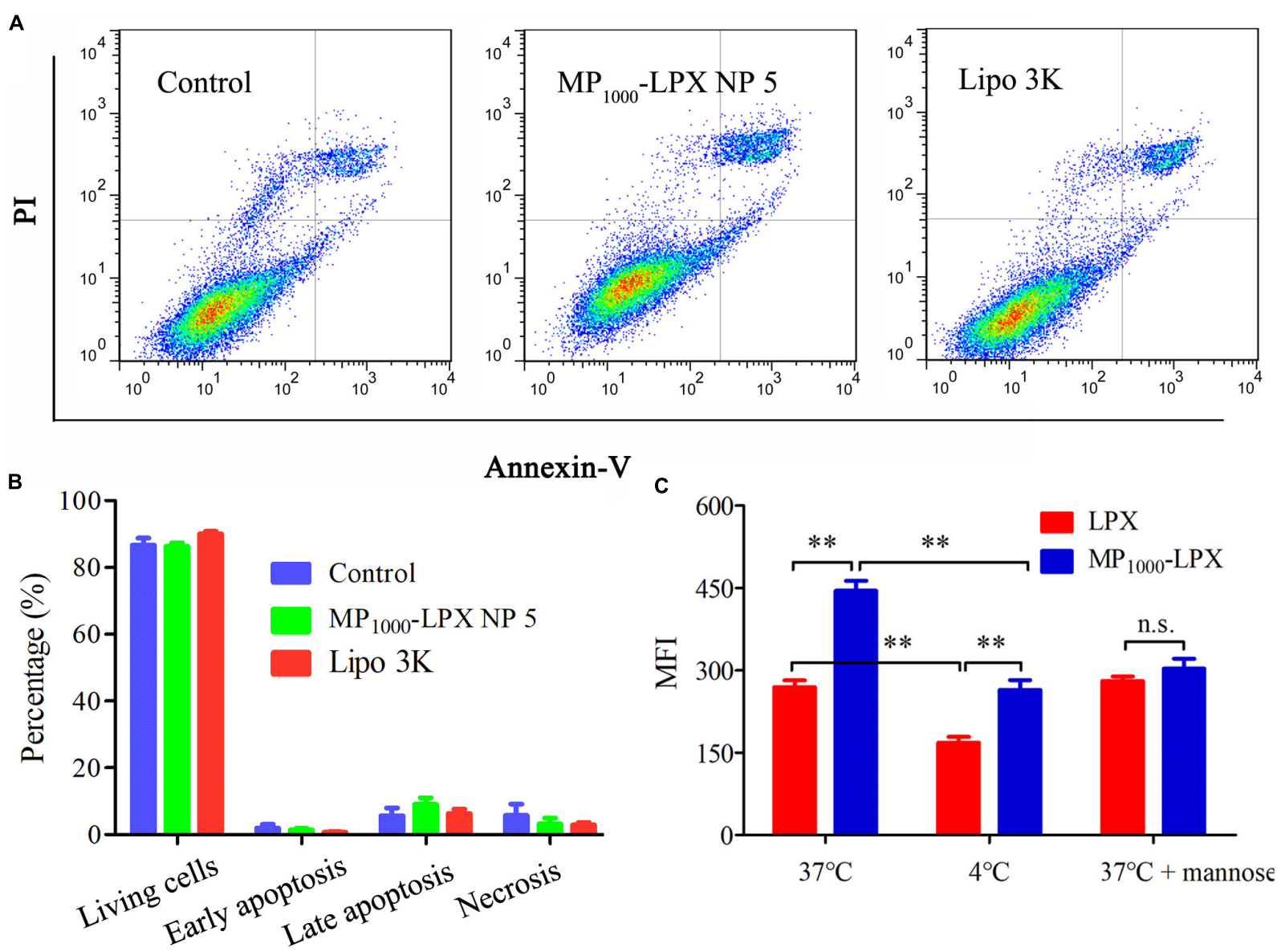

FIGURE 7 | Cytotoxicity and uptake assay of MP 1000 -LPX on DC2.4 cells. (A,B) Flow cytometry measurement of cell apoptosis induced by MP 1000 -LPX NP 5 and Lipo3K on DC2.4 cells. The data showed mean \pm SEM from a representative experiment from three independent experiments. (C) Cellular uptake mediated by mannose receptor at different conditions, including incubated at 4,37 , or $37^{\circ} \mathrm{C}$ with free mannose. ${ }^{*} p<0.05 ; * * p<0.01$.

of $\mathrm{MP}_{1000}$-LPX is optimal for transfection by DC2.4 cells but selected $\mathrm{MP}_{1000}$-LPX as a representative formulation from our result for further investigation.

The pharmaceutical properties including particle size, zeta potential, storage stability and the ability to protect mRNA against serum degradation of optimal $\mathrm{MP}_{1000}$-LPX were then characterized systemically. MP 1000 -LPX displayed bigger diameter and lower zeta potential compared to $\mathrm{MP}_{1000}$-LPs, indicating the complexation of $\mathrm{MP}_{1000}$-LPs with mRNA. We were surprised to find that particle size measurement results of $\mathrm{MP}_{1000}$-LPX by Zetasizer Nano ZS90 was much larger than that by TEM although some other researchers also observed the similar phenomenon (Wang K. et al., 2018; Yang et al., 2018). The larger size distribution by Zetasizer than TEM observed in the field of size measurement partially resulted from the interference of the dispersant into the hydrodynamic diameter. Complete complexation of the mRNA with $\mathrm{MP}_{1000}$-LPs was also validated according to the results of gel electrophoresis retardation assay. The preliminary storage stability experiment revealed that $\mathrm{MP}_{1000}$-LPX could maintain its excellent transfection efficiency at least for 3 days at $4^{\circ} \mathrm{C}$, which might benefit from the protection of the mRNA against degradation. It has been reported that triMNLPR with high zeta potential (about $35 \mathrm{mV}$ ) could better target human and murine dendritic cells, result in higher recruitments of DCs to draining lymph nodes, and induced significant antitumor responses (Le Moignic et al., 2018). Additionally, Folate modified cationic LPs loaded with DNMT1 gene with positive charge $(>30 \mathrm{mV})$ exerted excellent in vitro targeted genome editing and in vivo antitumor effects (He et al., 2018). However, there seemed to be much cationic charge in the $\mathrm{MP}_{1000^{-}}$ LPX. Further formulation optimization will be done to balance the transfection efficiency and the high positive zeta potential in our future work.

The cellular cytotoxicity and uptake mechanism of $\mathrm{MP}_{1000}$-LPX were also evaluated. $\mathrm{MP}_{1000}$-LPX presented good safety in vitro according to the data of cell apoptosis and might be a safe formulation for in vivo application. It has been reported that the presence of free mannose could decrease the uptake of mannose modified preparations (Li et al., 2013; Wang C. et al., 2014). The amount of free mannose in this study was used according to a previously reported literature (Wang C. et al., 2014). Moreover, the experiment design was similar to 
previous reports (Li et al., 2013; Wang C. et al., 2014). When DC2.4 cells were pretreated with free mannose as an inhibitor, no significant effect on uptake by LPX was observed, while uptake by $\mathrm{MP}_{1000}$-LPX was significantly decreased. This difference in uptake indicated that the enhanced uptake and transfection were mainly through the MR on DC2.4 cells in line with previous reports (Li et al., 2013; Wang C. et al., 2014). Taken together, our results of uptake in vitro confirmed that the enhanced transfection of $\mathrm{MP}_{1000}$-LPX occurs mainly via a MR-mediated mechanism and the linker length of mannose exerts a crucial role. Although $\mathrm{MP}_{1000}$-LPX exhibited higher level of transfection efficiency through the MR than MP $100-L P X$ and MP $2000-L P X$, we could not exclude that other linker length of mannose modified cholesterol would exhibit more effective transfection in DC2.4 cells through MR. Nevertheless, a rational design element was proposed and more detailed future studies will be indispensable to facilitate the progression of mRNA nanovaccine.

\section{CONCLUSION}

In summary, $\mathrm{MP}_{\mathrm{n}}-\mathrm{CH}$ with different linker molecules $\left(\mathrm{PEG}_{100}\right.$, $\mathrm{PEG}_{1000}$, and PEG 2000 ) were successfully synthesized by a simple and cost-efficient method. The DC-targeting LPs complexed with mRNA were self-assembled using $\mathrm{MP}_{\mathrm{n}}-\mathrm{CH}$ s as the targeting lipids. The linker molecules had no effect on the particle size and zeta potential of LPs and mRNA-complexed LPs but significantly affected the transfection efficiency of GFP-encoding mRNA. Unexpectedly, $\mathrm{PEG}_{1000}$ rather than $\mathrm{PEG}_{100}$ or the commonly used $\mathrm{PEG}_{2000}$ as the linker achieved the maximal level of GFP expression. $\mathrm{MP}_{1000}$-LPX containing $\mathrm{MP}_{1000}-\mathrm{CH}$ displayed good

\section{REFERENCES}

Avci-Adali, M., Behring, A., Keller, T., Krajewski, S., Schlensak, C., and Wendel, H. P. (2014). Optimized conditions for successful transfection of human endothelial cells with in vitro synthesized and modified mRNA for induction of protein expression. J. Biol. Eng. 8:8. doi: 10.1186/1754-1611-8-8

Bertrand, N., Grenier, P., Mahmoudi, M., Lima, E. M., Appel, E. A., Dormont, F., et al. (2017). Mechanistic understanding of in vivo protein corona formation on polymeric nanoparticles and impact on pharmacokinetics. Nat. Commun. 8:777. doi: 10.1038/s41467-017-00600-w

Caminschi, I., Maraskovsky, E., and Heath, W. R. (2012). Targeting dendritic cells in vivo for cancer therapy. Front. Immunol. 3:13. doi: 10.3389/fimmu.2012. 00013

Chen, D., Koropatnick, J., Jiang, N., Zheng, X., Zhang, X., Wang, H., et al. (2014). Targeted siRNA silencing of indoleamine 2, 3-dioxygenase in antigenpresenting cells using mannose-conjugated liposomes: a novel strategy for treatment of melanoma. J. Immunother. 37, 123-134. doi: 10.1097/CJI. 0000000000000022

Chen, J., Son, H. N., Hill, J. J., Srinivasan, S., Su, F. Y., Stayton, P. S., et al. (2016). Nanostructured glycopolymer augmented liposomes to elucidate carbohydrate-mediated targeting. Nanomedicine 12, 2031-2041. doi: 10.1016/j.nano.2016.05.001

Chen, J. L., Luo, J., Zhao, Y., Pu, L. Y., Lu, X. J., Gao, R., et al. (2015). Increase in transgene expression by pluronic L64-mediated endosomal/lysosomal escape through its membrane-disturbing action. ACS Appl. Mater. Interfaces 7, 7282-7293. doi: 10.1021/acsami.5b00486

Engel, A., Chatterjee, S. K., Al-arifi, A., Riemann, D., Langner, J., and Nuhn, P. (2003). Influence of spacer length on interaction of mannosylated liposomes with human phagocytic cells. Pharm. Res. 20, 51-57. doi: 10.1023/A: 1022294624256 profiles including small size with nearly spherical shape, good stability in serum and little cytotoxicity, indicating a hopeful DCs-targeting delivery system for mRNA vaccine.

\section{AUTHOR CONTRIBUTIONS}

XS conceived the project. MF and JW designed the experiments. FW, WX, and XB conducted most of the experiments. WX and QZ further performed and analyzed the transfection and characterization of formulations. FW, ME, and WX drafted the manuscript. LG and SY performed the ${ }^{1} \mathrm{H}-\mathrm{NMR}$ and HPLC analysis. QZ and YZ performed the some preliminary experiments. WX, QZ, and AF participated in literature searching. XS and MF finished the manuscript editing. All authors reviewed and approved the manuscript.

\section{FUNDING}

This work was financially supported by National Key S\&T Special Projects (2018ZX09201018-024) and Sichuan Province Science and Technology Support Program (2015SZ 0234).

\section{SUPPLEMENTARY MATERIAL}

The Supplementary Material for this article can be found online at: https://www.frontiersin.org/articles/10.3389/fphar. 2018.00980/full\#supplementary-material

Giacca, M., and Zacchigna, S. (2012). Virus-mediated gene delivery for human gene therapy. J. Control. Release 161, 377-388. doi: 10.1016/j.jconrel.2012.04.008

Hajj, K. A., and Whitehead, K. A. (2017). Tools for translation: non-viral materials for therapeutic mRNA delivery. Nat. Rev. Mater. 2:17056. doi: 10. 1038/natrevmats.2017.56

He, Z., Yu, Y., Zhang, Y., Yan, Y., Zheng, Y., He, J., et al. (2013). Gene delivery with active targeting to ovarian cancer cells mediated by folate receptor alpha. J. Biomed. Nanotechnol. 9, 833-844. doi: 10.1166/jbn.2013.1587

He, Z. Y., Wei, X. W., Luo, M., Luo, S. T., Yang, Y., Yu, Y. Y., et al. (2013). Folatelinked lipoplexes for short hairpin RNA targeting claudin-3 delivery in ovarian cancer xenografts. J. Control. Release 172, 679-689. doi: 10.1016/j.jconrel.2013. 10.015

He, Z. Y., Zhang, Y. G., Yang, Y. H., Ma, C. C., Wang, P., Du, W., et al. (2018). In Vivo Ovarian Cancer Gene Therapy Using CRISPR-Cas9. Hum. Gene Ther. 29, 223-233. doi: 10.1089/hum.2017.209

He, Z. Y., Zheng, X., Wu, X. H., Song, X. R., He, G., Wu, W. F., et al. (2010). Development of glycyrrhetinic acid-modified stealth cationic liposomes for gene delivery. Int. J. Pharm. 397, 147-154. doi: 10.1016/j.ijpharm.2010.06.029

Hua, S., and Wu, S. Y. (2013). The use of lipid-based nanocarriers for targeted pain therapies. Front. Pharmacol. 4:143. doi: 10.3389/fphar.2013.00143

Jeong, H. S., Na, K. S., Hwang, H., Oh, P. S., Kim, D. H., Lim, S. T., et al. (2014). Effect of space length of mannose ligand on uptake of mannosylated liposome in RAW 264.7 cells: in vitro and in vivo studies. J. Biomed. Mater. Res. A 102, 4545-4553. doi: 10.1002/jbm.a.35112

Kawakami, S., Sato, A., Nishikawa, M., Yamashita, F., and Hashida, M. (2000). Mannose receptor-mediated gene transfer into macrophages using novel mannosylated cationic liposomes. Gene Ther. 7, 292-299. doi: 10.1038/sj.gt. 3301089

Kim, H., Kim, B. H., Huh, B. K., Yoo, Y. C., Heo, C. Y., Choy, Y. B., et al. (2017). Surgical suture releasing macrophage-targeted drug-loaded nanoparticles for an 
enhanced anti-inflammatory effect. Biomater. Sci. 5, 1670-1677. doi: 10.1039/ c7bm00345e

Kim, H. K., Wei, H., Kulkarni, A., Pogranichniy, R. M., and Thompson, D. H. (2012). Effective targeted gene delivery to dendritic cells via synergetic interaction of mannosylated lipid with DOPE and BCAT. Biomacromolecules 13, 636-644. doi: 10.1021/bm2014119

Kranz, L. M., Diken, M., Haas, H., Kreiter, S., Loquai, C., Reuter, K. C., et al. (2016). Systemic RNA delivery to dendritic cells exploits antiviral defence for cancer immunotherapy. Nature 534, 396-401. doi: 10.1038/nature18300

Kreiter, S., Vormehr, M., van de Roemer, N., Diken, M., Lower, M., Diekmann, J., et al. (2015). Mutant MHC class II epitopes drive therapeutic immune responses to cancer. Nature 520, 692-696. doi: 10.1038/nature14426

Lai, C., Duan, S., Ye, F., Hou, X., Li, X., Zhao, J., et al. (2018). The enhanced antitumor-specific immune response with mannose- and CpG-ODN-coated liposomes delivering TRP2 peptide. Theranostics 8, 1723-1739. doi: 10.7150/ thno.22056

Le Moignic, A., Malard, V., Benvegnu, T., Lemiegre, L., Berchel, M., Jaffres, P. A., et al. (2018). Preclinical evaluation of mRNA trimannosylated lipopolyplexes as therapeutic cancer vaccines targeting dendritic cells. J. Control. Release 278, 110-121. doi: 10.1016/j.jconrel.2018.03.035

Lee, K., Yu, P., Lingampalli, N., Kim, H. J., Tang, R., and Murthy, N. (2015). Peptide-enhanced mRNA transfection in cultured mouse cardiac fibroblasts and direct reprogramming towards cardiomyocyte-like cells. Int. J. Nanomed. 10, 1841-1854. doi: 10.2147/IJN.S75124

Li, L., Li, X., Wu, Y., Song, L., Yang, X., He, T., et al. (2017a). Multifunctional nucleus-targeting nanoparticles with ultra-high gene transfection efficiency for in vivo gene therapy. Theranostics 7, 1633-1649. doi: 10.7150/thno.17588

Li, L., Song, L., Liu, X., Yang, X., Li, X., He, T., et al. (2017b). Artificial virus delivers CRISPR-Cas9 system for genome editing of cells in mice. ACS Nano 11, 95-111. doi: 10.1021/acsnano.6b04261

Li, P., Chen, S., Jiang, Y., Jiang, J., Zhang, Z., and Sun, X. (2013). Dendritic cell targeted liposomes-protamine-DNA complexes mediated by synthetic mannosylated cholesterol as a potential carrier for DNA vaccine. Nanotechnology 24:295101. doi: 10.1088/0957-4484/24/29/295101

Li, X. Y., Zhao, Y., Sun, M. G., Shi, J. F., Ju, R. J., Zhang, C. X., et al. (2014). Multifunctional liposomes loaded with paclitaxel and artemether for treatment of invasive brain glioma. Biomaterials 35, 5591-5604. doi: 10.1016/ j.biomaterials.2014.03.049

Malissen, B., Tamoutounour, S., and Henri, S. (2014). The origins and functions of dendritic cells and macrophages in the skin. Nat. Rev. Immunol. 14, 417-428. doi: $10.1038 /$ nri3683

Markov, O. V., Mironova, N. L., Shmendel, E. V., Serikov, R. N., Morozova, N. G., Maslov, M. A., et al. (2015). Multicomponent mannose-containing liposomes efficiently deliver RNA in murine immature dendritic cells and provide productive anti-tumour response in murine melanoma model. J. Control. Release 213, 45-56. doi: 10.1016/j.jconrel.2015. 06.028

McLenachan, S., Zhang, D., Palomo, A. B., Edel, M. J., and Chen, F. K. (2013). mRNA transfection of mouse and human neural stem cell cultures. PLoS One 8:e83596. doi: 10.1371/journal.pone.0083596

Midoux, P., and Pichon, C. (2015). Lipid-based mRNA vaccine delivery systems. Expert Rev. Vaccines 14, 221-234. doi: 10.1586/14760584.2015.986104

Monopoli, M. P., Aberg, C., Salvati, A., and Dawson, K. A. (2012). Biomolecular coronas provide the biological identity of nanosized materials. Nat. Nanotechnol. 7, 779-786. doi: 10.1038/nnano.2012.207

Nguyen, H., Katavic, P., Bashah, N. A. H., and Ferro, V. (2016). Synthesis of mannose-cholesterol conjugates for targeted liposomal drug delivery. ChemistrySelect 1, 31-35. doi: 10.1002/slct.201600007

Oberli, M. A., Reichmuth, A. M., Dorkin, J. R., Mitchell, M. J., Fenton, O. S., Jaklenec, A., et al. (2017). Lipid nanoparticle assisted mRNA delivery for potent cancer immunotherapy. Nano Lett. 17, 1326-1335. doi: 10.1021/acs.nanolett. 6b03329

Pan, Z., Fang, D., Song, N., Song, Y., Ding, M., Li, J., et al. (2017). Surface distribution and biophysicochemical properties of polymeric micelles bearing gemini cationic and hydrophilic groups. ACS Appl. Mater. Interfaces 9, 2138-2149. doi: 10.1021/acsami.6b14339

Pardi, N., Hogan, M. J., Porter, F. W., and Weissman, D. (2018). mRNA vaccines a new era in vaccinology. Nat. Rev. Drug Discov. 17, 261-279. doi: 10.1038/nrd. 2017.243
Persano, S., Guevara, M. L., Li, Z., Mai, J., Ferrari, M., Pompa, P. P., et al. (2017). Lipopolyplex potentiates anti-tumor immunity of mRNA-based vaccination. Biomaterials 125, 81-89. doi: 10.1016/j.biomaterials.2017.02.019

Rull-Barrull, J., d'Halluin, M., Le Grognec, E., and Felpin, F. X. (2016). Harnessing the dual properties of thiol-grafted cellulose paper for click reactions: a powerful reducing agent and adsorbent for $\mathrm{Cu}$. Angew. Chem. Int. Ed Engl. 55, 13549-13552. doi: 10.1002/anie.201606760

Sahin, U., Kariko, K., and Tureci, O. (2014). mRNA-based therapeutics-developing a new class of drugs. Nat. Rev. Drug Discov. 13, 759-780. doi: 10.1038/nrd4278

Sayour, E. J., De Leon, G., Pham, C., Grippin, A., Kemeny, H., Chua, J., et al. (2017). Systemic activation of antigen-presenting cells via RNA-loaded nanoparticles. Oncoimmunology 6:e1256527. doi: 10.1080/2162402X.2016.1256527

Shariat, S., Badiee, A., Jalali, S. A., Mansourian, M., Yazdani, M., Mortazavi, S. A., et al. (2014). P5 HER2/neu-derived peptide conjugated to liposomes containing MPL adjuvant as an effective prophylactic vaccine formulation for breast cancer. Cancer Lett. 355, 54-60. doi: 10.1016/j.canlet.2014.09.016

Stefanick, J. F., Ashley, J. D., Kiziltepe, T., and Bilgicer, B. (2013). A systematic analysis of peptide linker length and liposomal polyethylene glycol coating on cellular uptake of peptide-targeted liposomes. ACS Nano 7, 2935-2947. doi: $10.1021 / \mathrm{nn} 305663 \mathrm{e}$

Tsui, N. B., Ng, E. K., and Lo, Y. M. (2002). Stability of endogenous and added RNA in blood specimens, serum, and plasma. Clin. Chem. 48, 1647-1653.

Verbeke, R., Lentacker, I., Wayteck, L., Breckpot, K., Van Bockstal, M., Descamps, B., et al. (2017). Co-delivery of nucleoside-modified mRNA and TLR agonists for cancer immunotherapy: restoring the immunogenicity of immunosilent mRNA. J. Control. Release 266, 287-300. doi: 10.1016/j.jconrel. 2017.09.041

Wang, C., Liu, P., Zhuang, Y., Li, P., Jiang, B., Pan, H., et al. (2014). Lymphatic-targeted cationic liposomes: a robust vaccine adjuvant for promoting long-term immunological memory. Vaccine 32, 5475-5483. doi: 10.1016/j.vaccine.2014.07.081

Wang, C., Liu, P., Zhuang, Y., Li, P., Jiang, B., Pan, H., et al. (2015). Lymphatictargeted cationic liposomes: a robust vaccine adjuvant for promoting long-term immunological memory. J. Control. Release 213:e16. doi: 10.1016/j.jconrel.2015. 05.022

Wang, F., Bao, X., Fang, A., Li, H., Zhou, Y., Liu, Y., et al. (2018). Nanoliposomeencapsulated Brinzolamide-hydropropyl-beta-cyclodextrin inclusion complex: a potential therapeutic ocular drug-delivery system. Front. Pharmacol. 9:91. doi: 10.3389/fphar.2018.00091

Wang, K., Wen, S., He, L., Li, A., Li, Y., Dong, H., et al. (2018). Minimalist" nanovaccine constituted from near whole antigen for cancer immunotherapy. ACS Nano 12, 6398-6409. doi: 10.1021/acsnano.8b00558

Wang, N., Wang, T., Zhang, M., Chen, R., Niu, R., and Deng, Y. (2014). Mannose derivative and lipid A dually decorated cationic liposomes as an effective cold chain free oral mucosal vaccine adjuvant-delivery system. Eur. J. Pharm. Biopharm. 88, 194-206. doi: 10.1016/j.ejpb.2014.04.007

Xu, B., Jin, Q., Zeng, J., Yu, T., Chen, Y., Li, S., et al. (2016). Combined tumor- and neovascular-"dual targeting" gene/chemo-therapy suppresses tumor growth and angiogenesis. ACS Appl. Mater. Interfaces 8, 25753-25769. doi: 10.1021/ acsami.6b08603

Yang, R., Xu, J., Xu, L., Sun, X., Chen, Q., Zhao, Y., et al. (2018). Cancer cell membrane-coated adjuvant nanoparticles with mannose modification for effective anticancer vaccination. ACS Nano doi: 10.1021/acsnano.7b09041 [Epub ahead of print].

Yang, Y., He, L., Liu, Y., Xia, S., Fang, A., Xie, Y., et al. (2016). Promising nanocarriers for PEDF gene targeting delivery to cervical cancer cells mediated by the over-expressing FRalpha. Sci. Rep. 6:32427. doi: 10.1038/srep32427

Conflict of Interest Statement: The authors declare that the research was conducted in the absence of any commercial or financial relationships that could be construed as a potential conflict of interest.

Copyright (๑) 2018 Wang, Xiao, Elbahnasawy, Bao, Zheng, Gong, Zhou, Yang, Fang, Farag, $W u$ and Song. This is an open-access article distributed under the terms of the Creative Commons Attribution License (CC BY). The use, distribution or reproduction in other forums is permitted, provided the original author(s) and the copyright owner(s) are credited and that the original publication in this journal is cited, in accordance with accepted academic practice. No use, distribution or reproduction is permitted which does not comply with these terms. 